\title{
(6) Diagnosis and management of adult coeliac disease: guidelines from the British Society of Gastroenterology
}

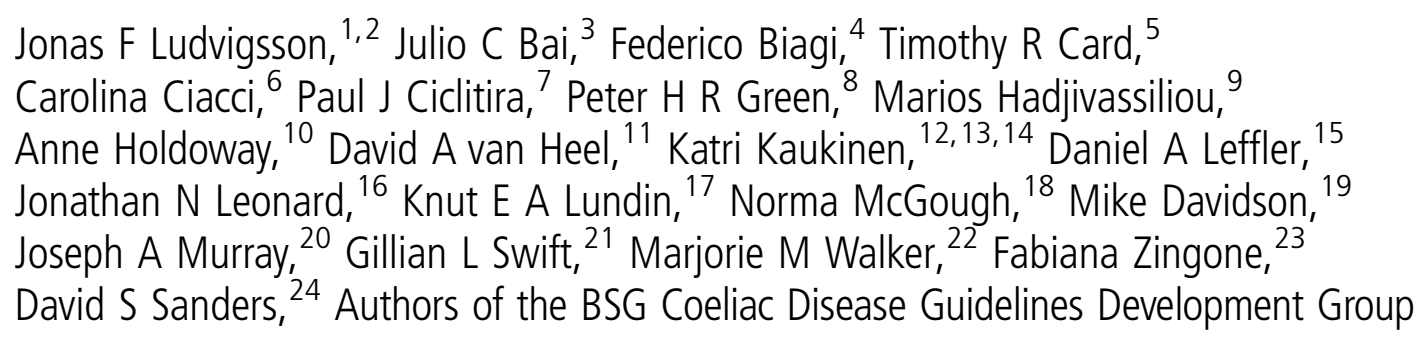

For numbered affiliations see end of article.

Correspondence to David S Sanders,

Gastroenterology and Liver Unit, Royal Hallamshire Hospital \& University of Sheffield, Sheffield S10 2JF, UK; david.sanders@sth.nhs.uk

Received 12 December 2013 Revised 23 April 2014 Accepted 25 April 2014 Published Online First 10 June 2014

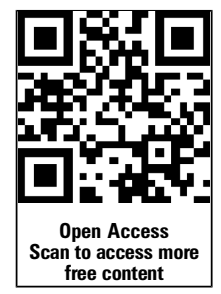

CrossMark

To cite: Ludvigsson JF, Bai JC, Biagi $F$, et al. Gut 2014;63:1210-1228.

\section{ABSTRACT}

A multidisciplinary panel of 18 physicians and 3 nonphysicians from eight countries (Sweden, UK, Argentina, Australia, Italy, Finland, Norway and the USA) reviewed the literature on diagnosis and management of adult coeliac disease (CD). This paper presents the recommendations of the British Society of Gastroenterology. Areas of controversies were explored through phone meetings and web surveys. Nine working groups examined the following areas of $C D$ diagnosis and management: classification of $C D$; genetics and immunology; diagnostics; serology and endoscopy; follow-up; gluten-free diet; refractory $C D$ and malignancies; quality of life; novel treatments; patient support; and screening for CD.

\section{Recommendations}

- Diagnosis of CD requires duodenal biopsy when the patient is on a gluten-containing diet and for the vast majority of adult patients also positive serology. (Grade B)

- Biopsy remains essential for the diagnosis of adult $\mathrm{CD}$ and cannot be replaced by serology. Follow-up should aim at strict adherence to a gluten-free diet. (Grade B)

\section{INTRODUCTION \\ Objective}

The aim was to create updated guidelines for the management of adult coeliac disease (CD), but non-coeliac gluten sensitivity (NCGS) was not considered.

\section{Development of the guidelines}

The British Society of Gastroenterology (BSG) guidelines on the management of adult $\mathrm{CD}$ were originally published in 1996. Recently the European Society for Paediatric Gastroenterology, Hepatology and Nutrition (ESPGHAN) published updated guidelines for paediatric $\mathrm{CD},{ }^{1}$ but international guidelines for adult $\mathrm{CD}$ are scarce ${ }^{2-5}$ since the NIH consensus ${ }^{6}$ on CD in 2005 (despite more than 4000 PubMed publications about CD in the last 8 years). As a result, the Clinical Services and Standards Committee of the BSG commissioned these guidelines, subject to rigorous peer review and based on a comprehensive review of the recent literature, including data from any available randomised controlled trials, systematic reviews, meta-analyses, cohort studies, prospective and retrospective studies.

A multidisciplinary panel of 18 physicians from eight countries (Sweden, UK, Argentina, Australia, Italy, Finland, Norway and the USA), a dietitian and a representative and a patient advocate from Coeliac UK reviewed the literature on the management of CD. These individuals were involved in the original stakeholder meetings and with revision of the manuscript.

\section{Intent and levels of evidence}

All aspects of the contemporary diagnosis and management of patients with adult $\mathrm{CD}$ were considered. PubMed literature was searched from 1900 to 2012 to obtain evidence for these guidelines. Also there was input from all authors who have considerable expertise and experience in diagnosis and management of CD. The panel of international experts previously collaborated in the publication of definitions of $\mathrm{CD}^{7}$ and were invited by the BSG through coauthor DSS. Our task force contained representatives from the clinical disciplines gastroenterology, paediatrics, histopathology, neurology, dermatology, genetics and immunology.

The current literature of review papers was examined, focusing on 10 reviews $^{8-17}$ to explore gaps in current reviews on $\mathrm{CD}$. Nine working subgroups were then formed that examined the following areas of $\mathrm{CD}$ management: classification of $\mathrm{CD}$ : $\mathrm{FB}, \mathrm{MH}$, DSS, CC; genetics and immunology: KEAL, DaVH, PJC; diagnostic criteria, serology and endoscopy in the investigation of CD: MMW, JAM, FB, PHRG, JFL, KEAL; follow-up: DAL, PHRG, JCB, JFL; gluten-free diet (GFD): PJC, KK, CC, GLS; refractory CD (RCD) and complications: FZ, FB, DAL, PHRG; quality of life (QoL): GLS, JCB, TRC, FZ; novel therapy: JCB, KEAL; screening for CD: TRC, KK, JAM, JFL. The working groups wrote the sections, which were subsequently internally reviewed. Each final fully written and 
referenced section was then released to all group members for review by teleconference and email correspondence. Thereafter JFL created the first draft of the guidelines by amalgamating all documents. All authors then helped revise this draft until final document consensus was reached.

Between January 2012 and February 2013, six web surveys were performed using the web site 'survey console' (http://www. surveyconsole.com) to explore issues including coeliac topics of controversy; the role of endoscopy; the role of histopathology and serology in the diagnosis of CD; and follow-up of patients, including the use of follow-up biopsy. The web surveys were for the coauthors/Guidelines Development Group (GDG) members. Survey results were then discussed at teleconference and used to inform the direction of recommendations and outline areas where the GDG were not concordant. Disagreements were solved through discussion.

Studies used as a basis for these guidelines are graded according to the quality of evidence using the Oxford Centre for Evidence-based Medicine levels of evidence. ${ }^{18}$

\section{Strength of recommendations}

A. Directly based on category I evidence, for example, from systematic reviews and randomised controlled trials. This is the strongest recommendation of the four grades listed.

B. Directly based on category II or III evidence or extrapolated recommendation from category I evidence. This includes evidence from controlled non-randomised studies or time series; or indirect evidence from systematic reviews or randomised controlled trials.

C. Directly based on category IV evidence or extrapolated recommendation from category II or III evidence. This also includes evidence from non-experimental studies such as cohort studies or case-control studies.

D. Directly based on category $\mathrm{V}$ evidence or inconsistent or inconclusive studies of any level. This includes evidence from expert committees and respected authorities.

\section{BACKGROUND}

$\mathrm{CD}$ is an immune-mediated small intestinal enteropathy that is triggered by exposure to dietary gluten in genetically predisposed individuals. ${ }^{7}$ Samuel Gee is credited with the first clinical description of CD in 1887, although Aretaeus of Cappadocia may have described the disease in the first century AD. In the 1930s and 1940s, Dicke demonstrated (then published in $1953^{19}$ ) that a wheat-free diet was the key to management. The discovery of antigliadin antibodies in 1961 was the first noninvasive serological marker for CD. ${ }^{20}$

Until the 1980s, CD was considered a rare disease affecting mainly children (exceptions occurred ${ }^{21}$ ), but subsequently has been shown to occur at any age. ${ }^{22}$ Although the prevalence seems to vary considerably (from $<0.25 \%{ }^{23}$ to $>1 \%{ }^{24}$ ), a large-scale screening study in subjects from Finland, Italy, the UK and Germany found a prevalence of CD of around $1 \%,{ }^{25-27}$ with a recent US study showing a prevalence of $0.71 \%{ }^{28} \mathrm{CD}$ is more frequently diagnosed in women than in men with a ratio between 1.5 and $2,{ }^{29}$ but this gender imbalance may vanish with age and has been absent in some screening studies. ${ }^{30}$

Traditionally patients with CD presented with malabsorption dominated by diarrhoea, steatorrhoea, weight loss or failure to thrive ('classical CD'), ${ }^{7}$ but over time the proportion of newly diagnosed patients with malabsorptive symptoms has decreased, ${ }^{31}$ and 'non-classical $\mathrm{CD}^{, 7}$ and even asymptomatic CD have gained prominence. Newly diagnosed patients with $\mathrm{CD}$ can present with a wide range of symptoms and signs, including anaemia, ${ }^{32}$ vague abdominal symptoms (often similar to irritable bowel syndrome (IBS) ${ }^{33}$ ), neuropathy, ${ }^{34}{ }^{35}$ ataxia, ${ }^{36}$ depression, ${ }^{37}$ short stature, ${ }^{38}$ osteomalacia and osteoporosis, ${ }^{39}$ liver disease, ${ }^{40}$ adverse pregnancy outcomes ${ }^{41}$ and lymphoma. ${ }^{42}$ Asymptomatic patients are typically diagnosed through screening. Screening may be initiated because the individual has a $\mathrm{CD}$-associated disorder or has symptoms and is a first-degree relative to a patient with $\mathrm{CD}$.

The diversity of the clinical presentation of CD emphasises the need for robust diagnostic criteria and careful disease work-up. It is therefore natural that over the years, several efforts have been made to define CD, ${ }^{1}{ }^{7} 43-45$ and how it should be managed. ${ }^{8-16}$ While all these reviews discussed critical aspects of diagnostics, including the small intestinal biopsy and serology, there are scant reports discussing the genetic and immunological background, ${ }^{8-14}$ the role of human leucocyte antigen (HLA) testing, ${ }^{11} 12151646$ and even fewer have discussed issues such as QoL ${ }^{11} 15$ and patient support. ${ }^{15}$

During our previous review on definitions of $\mathrm{CD}$ and related concepts, $^{7}$ we realised that there was a need for a consensus paper on modern management and diagnosis of CD. In this project, participants of the so-called Oslo group who first convened at the 2011 meeting on $\mathrm{CD}$ in $\mathrm{Oslo}^{7}$ collaborated with representatives of the BSG to write guidelines for the management of CD in adults. These guidelines will enable physicians, dietitian and other healthcare personnel to provide better care for their patients.

\section{GENETICS, IMMUNOLOGY AND TRIGGER FACTORS}

Environmental factors are important in CD and ingestion of gluten is a prerequisite for the development of $\mathrm{CD}$. Children breastfed at and beyond gluten introduction may be at lower risk of developing $\mathrm{CD}$ in childhood, although research is not consistent. ${ }^{47}$ Conversely, large amounts of gluten or gluten exposure without ongoing breastfeeding may increase the risk of future CD. ${ }^{48}{ }^{49}$ Gastrointestinal infections, drugs, interferon $\alpha$ and surgery have also been implicated as trigger factors. ${ }^{47} 5051$ The factors leading to the breakdown of tolerance to gluten are not known, but local pro-inflammatory changes are of paramount importance. ${ }^{52}$

A high prevalence (10\%) among first-degree relatives of patients with $\mathrm{CD}^{53}$ and a greater concordance rate in monozygotic twins $(\sim 75 \%)^{54}$ than in dizygotic twins indicates a strong genetic component.

CD shows a very strong association with a particular HLA variant termed HLA-DQ2.5. ${ }^{55}$ This molecule is encoded by the DQA1*05:01 and DQB1*02:01 genes in cis configuration on the DR3 haplotype. Thus most patients are DR3, DQ2 positive. A smaller subset of patients with $C D$ express a very similar DQ2.5 molecule encoded by a combination of DR5 and DR7 positive haplotypes, in this situation by the genes in trans position. While the proportion of individuals with CD who are DQ2.5 positive varies in different geographical areas it is generally $\geq 90 \%$. The majority of the remaining patients are HLA-DQ8 positive (DR4, DQ8 haplotype). ${ }^{56}$

Genome wide association studies have so far identified 40 loci outside of HLA with genes predisposing to or protecting against CD. ${ }^{57}$ Most of these genes have immunological functions and are related to B-cell and T-cell functions. Each of the non-HLA genes contributes little to genetic risk. With a population prevalence of $1 \%$ and a heritability of $50 \%$, the 39 non-HLA loci account for $14 \%$ of the genetic variance whereas HLA in comparison accounts for $40 \% .{ }^{57}$ 
The most striking morphological features of the active coeliac lesion are the infiltration in the epithelium of T-cell receptor $\alpha / \beta$ and $\gamma / \delta$ expressing CD8 positive T cells, natural killer cell like T cells, and the dense population in the lamina propria of plasma cells and activated antigen presenting cells. ${ }^{59}$ Although numerically not dominant, CD4 gluten reactive $\mathrm{T}$ cells (T-cell receptor $\alpha / \beta$ expressing $)^{61}{ }^{62}$ are crucial in the pathogenesis of $\mathrm{CD}$ and are not found in people without CD. ${ }^{63-65}$

The CD4, gluten-specific T cells in the lamina propria invariably recognise gluten presented by the disease-associated HLA-DQ2 and HLA-DQ8 molecules ${ }^{61-65}$ and recognise gliadin peptides that have been modified by tissue transglutaminase 2 (TG2). This modification (glutamine to glutamic acid deamidation process) introduces negative charges. ${ }^{66}$ These modifications produce peptides that bind with much higher affinity to the HLA-DQ2 and HLA-DQ8 molecules. ${ }^{67}$ Patients with CD who are untreated typically have high titres of antibodies against the endomysium antigen (EMA test), also shown to be the extracellular enzyme tissue TG2. ${ }^{68}$ On exposure to gluten, plasma cells produce antibodies to tissue transglutaminase (IgA-TG2) ${ }^{69}$ and deamidated gliadin peptides (IgA-DGP ${ }^{70}$ and IgG-DGP ${ }^{71}$ ).

Untreated and treated CD are characterised by an increase in $\gamma / \delta$ intraepithelial lymphocytes (IELs), although in treated disease, the IEL count is close to that in healthy individuals. ${ }^{72}$

\section{DIAGNOSTICS}

Diagnosis of CD is by serology and duodenal biopsy, ideally with the patient on a normal, that is, gluten-containing diet. Biopsy remains essential for the diagnosis of adult CD and cannot be replaced by serology. Exceptions are patients with coagulation disorders and pregnant women, in whom biopsy may not be feasible or should be postponed until postpartum.

To state definite diagnosis of CD, villous atrophy is required. However, lesser degrees of damage ( $\geq 25$ IELs but no villous atrophy) combined with positive serology (IgA-EMA, tissue transglutaminase (TTG) or IgG-DGP) may also represent CD ('probable CD'), and in these circumstances a trial with GFD may be considered to further support the diagnosis of CD. HLA status may also aid diagnosis. Differential diagnoses of lymphocytic duodenosis should be ruled out if there is no response to GFD (see table 2).

The diagnosis of CD is readily established in those who, while consuming a gluten-containing diet, have positive serology and a duodenal biopsy with obvious coeliac histology (increased intraepithelial lymphocytosis, crypt hyperplasia and villous atrophy; table 1). These patients can immediately initiate a GFD with confidence.

$\mathrm{CD}$ can also be suspected in patients with mild gastrointestinal symptoms, associated conditions or those at genetic risk. ${ }^{3}$ Such patients should be investigated initially with serology and if this is positive (or if there is still a high index of suspicion as among symptomatic first-degree relatives ${ }^{73}$ ), then undergo upper endoscopy and duodenal biopsies.

However, in some cases the diagnosis of CD may not be straightforward, for example, patients are already on a GFD and therefore antibodies are negative, biopsies were not oriented correctly (this could lead to false-negative or false-positive villous atrophy) or show solely intraepithelial lymphocytosis (lymphocytic duodenosis) $^{74}$ without architectural changes. In these situations, the patient needs to be maintained on a glutencontaining diet and further evaluated with additional testing and, if necessary, referred to a centre or clinician with a specific interest in CD.

The diagnosis of CD is illustrated in table 1.

\section{Serology in CD diagnosis}

Serological detection depends on the presence of specific endomysial antibodies (EMAs, also called AEAs), IgA anti-tissue

Table 1 An algorithm for the diagnosis of coeliac disease

\begin{tabular}{|c|c|c|c|c|c|c|c|}
\hline $\lg A-T G 2$ & Total IgA & IgG-TG2- & IgG-DGP & EMA & HLA & $\begin{array}{l}\text { Biopsy } \\
\text { showing CD type } \\
\text { histology* }\end{array}$ & Coeliac status \\
\hline \multicolumn{7}{|c|}{$\begin{array}{l}\text { Patient on a gluten-containing diet, IgA-TG2 or IgA-DGP, or IgG-DGP, EMA positive and the } \\
\text { biopsy shows villous atrophy }\end{array}$} & Coeliac \\
\hline \multicolumn{8}{|c|}{ For patients for whom the above criteria are not fulfilled, please see below } \\
\hline+ & Normal or ND & ND & ND & ND & ND & + & Coeliac if VA, otherwise probably coeliac \\
\hline+ & ND & ND & ND & + & + & + & Coeliac if VA, otherwise probably coeliac \\
\hline+ & ND & ND & ND & + & + & - & Potential celiact \\
\hline $\begin{array}{l}+ \text { (usually } \\
\text { low titre) }\end{array}$ & ND & ND & ND & - & - & - & Not coeliac \\
\hline- & Normal & - & - & - & + & - & Not coeliac \\
\hline- & Normal & - & - & - & - & - & Not coeliac \\
\hline- & Normal & - & - & - & - & + & $\begin{array}{l}\text { Unclear. Check serology when the patient is on a gluten-containing diet. } \\
\text { Evaluate response to gluten-free diet, and consider other causes of VA }\end{array}$ \\
\hline- & Normal & - & - & - & + & + & $\begin{array}{l}\text { Unclear. Check serology when the patient is on a gluten-containing diet. } \\
\text { Evaluate response to gluten-free diet, and consider other causes of VA }\end{array}$ \\
\hline- & Low/absent & + & + & - & + & + & $\begin{array}{l}\text { IgA deficient and celiac if biopsy shows VA. } \\
\text { Otherwise IgA deficient and probable coeliac }\end{array}$ \\
\hline- & Low/absent & - & - & - & - & - & IgA deficient, not coeliac \\
\hline- & Low/absentł & - & - & - & + & + & $\begin{array}{l}\text { ?post infectious diarrhoea } \\
\text { Combined immune deficiency syndrome }\end{array}$ \\
\hline
\end{tabular}

*Biopsy showing CD type histology = \pm villous atrophy, \pm crypt hyperplasia but must have intraepithelial lymphocytosis, IELs $\geq 25 / 100$ enterocytes.

tA duodenal biopsy may be negative when the lesion is only present in the jejunum.

$¥$ And the patient does not respond to a gluten-free diet.

$\mathrm{CD}$, coeliac disease; DGP, deamidated gliadin peptide; EMA, endomysium antigen; HLA, human leucocyte antigen; IEL, intraepithelial lymphocyte; ND, not done;

TG2, transglutaminase 2; VA, villous atrophy (Marsh 3). 
Table 2 Histological mimics of CD in seronegative patients-conditions to be considered for investigation in an appropriate clinical context

\begin{tabular}{|c|c|c|}
\hline \multicolumn{3}{|c|}{ Duodenal histology: normal architecture and increased IELs ( $\geq 25 / 100$ enterocytes) or villous atrophy \pm increased IELs ( $\geq 25 / 100$ enterocytes) } \\
\hline Immune disorders & \multicolumn{2}{|l|}{$\begin{array}{l}\text { Common variable immunodeficiency syndrome } \\
\text { Glomerulonephritis } \\
\text { Hypogammaglobulaemia } \\
\text { IgA deficiency }\end{array}$} \\
\hline \multirow{6}{*}{$\begin{array}{l}\text { Autoimmune disease } \\
\text { These patients may have concurrent CD, } \\
\text { check serology and HLA status if appropriate* }\end{array}$} & Autoimmune enteropathy (adults and children) & Rheumatoid arthritis \\
\hline & Graves' disease* & Sjögren's syndrome* \\
\hline & Haemolytic anaemia & Systemic lupus erythematosus \\
\hline & Hashimoto's thyroiditis* & Thymoma-associated autoimmune enteropathy \\
\hline & Multiple sclerosis & Type I diabetes mellitus* \\
\hline & Psoriasis & \\
\hline \multirow[t]{2}{*}{ Hypersensitivity/non-gluten protein intolerance } & Non-coeliac gluten sensitivity & \\
\hline & $\begin{array}{l}\text { Protein intolerance (cows' milk, soy, } \\
\text { eggs, peanuts, cereals) }\end{array}$ & \\
\hline \multirow[t]{5}{*}{ Infection } & AIDS & Small intestinal bacterial overgrowth \\
\hline & Cryptosporidium & Tropical sprue \\
\hline & Giardiasis & Tuberculosis (including atypical TB) \\
\hline & Helicobacter pylori gastritist & Viral \\
\hline & Postinfectious diarrhoea & Whipple's disease (for example, HIV) \\
\hline \multirow[t]{4}{*}{ Drugs } & Chemotherapy & \\
\hline & Non-steroidal anti-inflammatory drugs & \\
\hline & Olmesartan & \\
\hline & Mycophenolate mofetil & \\
\hline \multirow[t]{4}{*}{ Neoplasia } & Enteropathy-associated T-cell lymphoma & \\
\hline & Immunoproliferative small intestinal disease & \\
\hline & Refractory CD type 2 & \\
\hline & CD 4 T-cell proliferation & \\
\hline \multirow[t]{5}{*}{ Other } & Abetalipoproteinaemia & Eosinophilic gastroenteritis \\
\hline & Collagenous colitis & Glycogen storage disease \\
\hline & Collagenous duodenitis & Microscopic colitis \\
\hline & Crohn's disease & Radiation enteritis \\
\hline & & Small bowel ischaemia \\
\hline
\end{tabular}

transglutaminase antibodies (IgA-TG2, also called a-TTG, TTA) and/or deamidated antigliadin antibodies (DGP, either IgA or IgG isotype). ${ }^{7}$ IgG-TG2 is primarily useful in patients with known IgA deficiency. ${ }^{75} 76$

There is continuing debate on the sole use of non-invasive tests to diagnose CD. Recently ESPGHAN proposed new guidelines for the diagnosis of $C D$ in children. It suggests that in symptomatic paediatric patients ${ }^{1}$ in whom the IgA-TG2 level exceeds 10 times the upper limit of normal, EMA antibodies are positive on a separately taken blood sample, and HLA-DQ2 or HLA-DQ8 are positive, then biopsies do not need to be performed to confirm the diagnosis of CD. ${ }^{1}$ In adults, this strategy has also been proposed ${ }^{77}$; however, there are very strong arguments for retaining the biopsy as gold standard for the diagnosis of CD. A recent study from the (UK) National External Quality Assessment Service centre states that not all commercial IgA-TG2 kits are reliable and the ESPGHAN guidelines are therefore not translatable for use in all centres and should not be used in the UK. ${ }^{78}$ Also, $2 \%$ of patients with CD are IgA deficient $(0.2 \%$ of the population in general) and as usual serology tests for IgA-TG2 and EMA are IgA based, this may lead to false negatives and a reduction in test sensitivity. If patients are known to be IgA deficient, IgG-TG2 or IgG-DGP antibodies can be used, or alternatively, such patients should proceed directly to biopsy. ${ }^{79}$

A combination of immunoassays offers the best sensitivity if either a positive IgA-TG2 or IgG-DGP is considered a positive detection test. The combination of IgG-DGP and IgA-TG2 is particularly useful as an addition to detection of patients with $\mathrm{CD}$ who are IgA deficient, IgG-DGP was able to detect a few more IgA-sufficient patients who were missed by IgA-TG2 alone. $^{76}$

There are now several point-of-care tests commercially available, which allow both immediacy and the ability to use them in a physician office/primary care setting. However, there is a relative paucity of data on the sensitivity and specificity of such tests by comparison to the gold standard of duodenal biopsy. ${ }^{80}$ There is concern regarding the use of these tests as patients may start on a GFD without a firm diagnosis-which includes biopsyand further studies should be performed before considering the use of these in everyday practice. One study utilising community health nurses demonstrated a lower than expected sensitivity for $\mathrm{CD} .{ }^{81}$

\section{Endoscopy in seronegative individuals}

The prevalence of seronegative CD is $6-22 \%$ of all diagnosed cases. ${ }^{71} 828384$ One study also found a high degree of variability in EMA values for sensitivity between laboratories, ${ }^{85}$ and upper endoscopy is generally well tolerated and safe. ${ }^{86}$ Individuals of white European, Middle Eastern, North African or North Indian origin who undergo upper endoscopy for anaemia, weight loss or diarrhoea should therefore have duodenal biopsies performed, irrespective of whether they have had serology for CD. These features may well indicate that CD or an alternative mucosal cause of malabsorption is present. ${ }^{87}$ In 
fact, it has been suggested that duodenal biopsy should be considered in any individual undergoing endoscopy, because CD is common and has many varied clinical manifestations, including reflux, a common indication for endoscopy. ${ }^{88}$

\section{Recommendation}

- In individuals undergoing an upper endoscopy in whom laboratory tests or symptoms or endoscopic features suggest $C D$, duodenal biopsy should be considered. (Grade C)

\section{Role of HLA in the diagnosis of CD}

$\mathrm{CD}$ is associated with specific HLA types in virtually all populations in which this has been tested, and is associated with the carriage of the gene pairs that encode DQ2.5 and DQ8. ${ }^{46} 89$ The diagnostic value of HLA genotyping in patients who may have $\mathrm{CD}$ revolves around its high negative predictive value, meaning that patients who lack the appropriate HLA genotype pairs described above are very unlikely to have CD. ${ }^{90}$ However, the positive predictive value of the HLA genotyping for CD susceptibility is very low as a large proportion of individuals without CD carry either HLA-DQ2 or HLA-DQ8 (the prevalence of DQ2 in the general population varies between $0 \%$ and $40 \%$ while that of DQ8 varies between $0 \%$ and $20 \%$ between countries $^{91}$ ). In family screening, DQ2-positive or DQ8-positive relatives (especially siblings) are at a higher risk of $\mathrm{CD},{ }^{53} 92$ with one study suggesting that DQ2 positivity was associated with a 16 -fold increased risk of CD among first-degree relatives. ${ }^{53}$

\section{Specific use of HLA typing}

HLA genotyping may be used in patients with suspected CD but who fail to respond to a GFD. A negative test in this circumstance would indicate that patients are highly unlikely to have CD $(<1 \%$ of patients with CD are negative for DQ2 and $\mathrm{DQ} 8^{93}$ ) and thus the clinician can direct diagnostic efforts elsewhere. HLA typing may similarly be used in patients who are self-treated on a GFD and never had appropriate testing for CD before changing their diet. HLA typing may have an adjunctive role to identifying individuals who are not genetically at risk of $\mathrm{CD}$ and in whom further evaluation for CD is not necessary, saving a large number of repeated tests for $\mathrm{CD}$ in patients who would otherwise have to undergo testing because they have symptoms and a first-degree relative with CD. ${ }^{94}$

\section{Recommendations}

- HLA typing should be used to rule out CD. A positive DQ2.5 or DQ8 can never confirm the diagnosis. (Grade B)

- HLA typing should be used in individuals who are self-treated on a GFD and never had appropriate testing for $C D$ before changing their diet. (Grade $B$ )

- HLA typing can be used to rule out CD, and minimise future testing, in high-risk individuals with $C D$, for example, first-degree relatives. (Grade B)

\section{Biopsy and endoscopy in CD}

There are endoscopic markers of villous atrophy describedscalloping or reduction of duodenal folds and nodularity-but these are not sensitive enough to preclude a biopsy, ${ }^{95}$ and a normal endoscopic appearance may occur in the presence of villous atrophy. ${ }^{96-98}$ Therefore, the endoscopic appearance of the duodenum should not determine whether biopsy is performed.

Biopsy of the duodenum for a diagnosis of CD should be performed irrespective of the prior performance of serological tests, if the patient exhibits symptoms or signs of $\mathrm{CD}$, such as diarrhoea, weight loss or anaemia. Biopsies can be mounted on fibre-free paper to aid orientation, ${ }^{99}$ or alternatively biopsies could be free floated in formalin. Consultation with the histopathology laboratory is recommended to agree on specimen presentation.

The villous atrophy may be patchy in CD; hence multiple biopsies from the bulb and the more distal duodenum are recommended. The taking of at least four biopsy specimens is associated with a doubling of the diagnostic rate compared with patients undergoing a lower number of biopsies (less than four). ${ }^{100}$ In patients with persistently positive coeliac serology but a normal mucosa, repeat small intestinal biopsy should be considered, including biopsies from the jejunum. ${ }^{101}$ Video capsule endoscopy may support a CD diagnosis in this setting. ${ }^{102}$

A diagnosis of $\mathrm{CD}$ has implications for family members, as overall, around $10 \%$ of first-degree relatives ${ }^{53}$ may be affected and there could be uncertainty in pursuing this diagnosis in the family if the index case does not have a definite CD diagnosis. Within an adult population the patient may have other indications for an upper endoscopy, for example anaemia, and thus exclusion of other diseases is essential. Upper endoscopy is generally well tolerated by adults and, in contrast to children, can usually be readily performed with mild or even no sedation. Finally histological appearance of the small intestinal mucosa may also predict the risk of certain future complications, such as lymphoma (patients with villous atrophy are at statistically significantly higher risk of future lymphoma than patients with a normal mucosa but positive coeliac serology). ${ }^{103}$

Nevertheless there are still adult patients who may be unable or unwilling to undergo an endoscopy. Under these circumstances, assessment of the serological assay and/or level of IgA-TG2 (if 10 times the upper limit of normal), positive DGP/ EMA, or the use of capsule endoscopy may have a supportive role. The sensitivity of capsule endoscopy to detect CD is similar to that of conventional endoscopy when combined with biopsies. However, it is less invasive, with good specificity and may provide endoscopic images that can then be used to support the diagnosis of $\mathrm{CD}$ in conjunction with positive serology. This approach may also be taken in equivocal cases. 104105

\section{Recommendations}

- The diagnosis of $C D$ requires duodenal biopsy when the patient is on a gluten-containing diet and for the vast majority of adult patients also positive serology. (Grade B)

- Duodenal biopsy should be retained as the mainstay for the diagnosis of adult CD and cannot be replaced by serology. (Grade B)

- At endoscopy, if there is suspicion of $C D$, then at least four biopsy specimens should be obtained, including a duodenal bulb biopsy. (Grade C)

- In serologically negative patients showing signs of malabsorption (such as anaemia or diarrhoea) or a family history of $C D$, a duodenal biopsy should be considered. (Grade C) 


\section{Histopathology diagnosis of CD}

It is important that pathologists and clinicians appreciate that patients with CD benefit from a GFD regardless of the degree of damage in the small intestine and that minor degrees of histological change suggestive of CD should not be ignored. ${ }^{106}$

Marsh ${ }^{107}$ described a commonly used classification of this spectrum. This classification has been modified subsequently by Oberhuber $^{108}$ and simplified by Corazza and Villanacci. ${ }^{109}$ Recently, Rostami and Villanacci ${ }^{110}$ defined microscopic enteritis (also called lymphocytic duodenosis, ${ }^{111}$ lymphocytic enteropathy ${ }^{111}$ ) and Villanacci et $a l^{112}$ published a practical classification with a user-friendly checklist for the histology report of CD.

Some clinicians would prefer a descriptive report, and collaboration between pathologists and gastroenterologists as to the content of the report is valuable. It is important that if serology has not been performed prior to the biopsy, then this must be carried out by the requesting physician on receipt of a histology report suggesting a diagnosis of $\mathrm{CD}$. A biopsy finding of villous atrophy is not specific for CD. Although CD is the commonest cause of villous atrophy, there are other causes (table 2); for this reason the addition of coeliac-specific serology seals the diagnosis. The biopsies must be properly oriented (usually by an experienced laboratory technician) as correct orientation is necessary for assessment of villous height crypt depth ratio (derived from the well oriented fields of the biopsies) (figure 1).

The following features should be stated in the report:

- Number of biopsies (including those from the duodenal bulb) ${ }^{113}$ and orientation.

- The architectural features (normal, partial, sub-total or total villous atrophy).

- Comment on the content of the lamina propria (in CD these are lymphocytes, plasma cells and eosinophils, and occasionally neutrophils, but cryptitis and crypt abscesses should suggest other pathology).

- Presence of Brunner's glands.

- Presence of crypt hyperplasia, villous height: crypt depth ratio $(3: 1) .{ }^{112}$ The absence of plasma cells suggests common variable immunodeficiency.

- Evaluation of IELs (with immunocytochemical staining for T cells (CD3) in equivocal cases ${ }^{114}$ ) is vital. Counting IELs should be time efficient-simply counting IELs/20 enterocytes at the tips of five villi, ${ }^{115} 116$ or IELs per 50 enterocytes in two villi and summing these ${ }^{111}$ are both reliable and sensitive methods using H\&E staining methods. The normal count has been variably cited; however, in evidence-based practice $^{111}$ and in recent classifications, ${ }^{109} 112<2$ IIELs/100 enterocytes should be taken as the norm.

- Use of a simple classification system greatly enhances intra-observer agreement. ${ }^{117}$

\section{Other causes of lymphocytic duodenosis and villous atrophy}

Lymphocytic duodenosis ${ }^{74}$ is a common condition $3.8 \%$ of a population negative for coeliac serology ${ }^{111}$ ) seen in association with infection (particularly Helicobacter pylori), altered immune states, for example, common variable immunodeficiency, autoimmune and chronic inflammatory disorders, drugs and neoplasia. ${ }^{16} 118-120$ The villous architecture is normal, typically there is no crypt hyperplasia and IELs are $\geq 25 / 100$ enterocytes. Of note, in a single study $16 \%$ of cases of lymphocytic duodenosis were found to have CD, and in $66 \%$ a known association was found by further investigation. ${ }^{121}$ Similarly there are other causes of villous atrophy in duodenal biopsies, including immune disorders and deficiency, food hypersensitivity, infection, drugs, neoplasia and miscellaneous disorders $^{120} 122$ (table 2). In a study of non-coeliac enteropathy, $70 \%$ of patients with this condition were initially diagnosed as having CD. ${ }^{123}$

\section{NOVEL DIAGNOSTIC METHODS}

While the current standard tests of serology and conventional histology are usually adequate to reach a diagnosis of $\mathrm{CD}$, there are patients whose tests are equivocal and diagnostic uncertainty remains. Several novel diagnostic approaches have been undertaken. The deposition of $\operatorname{IgA}$ antibodies in close proximity to TG2 in the small intestine has shown promise as a way of defining early or potential CD in patients who are seropositive but lack any of the usual histological markers for CD. Recent work from Finland on IgA-TG2 autoantibody deposition in the small intestine in such patients shows promise in delivery of an early
Figure 1 Relationship between villous height and crypt depth. CD, crypt depth; IEL, intraepithelial lymphocyte; $L D$, lymphocytic duodenosis; PVA, partial villous atrophy; TVA, total villous atrophy; $\mathrm{VH}_{\text {, }}$ villous height. The dots represent IELs.

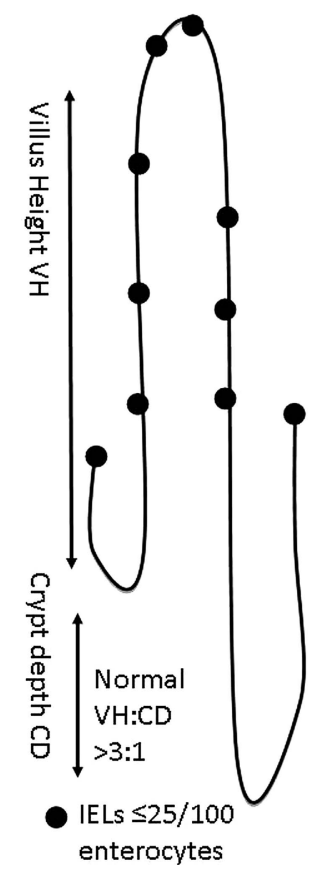

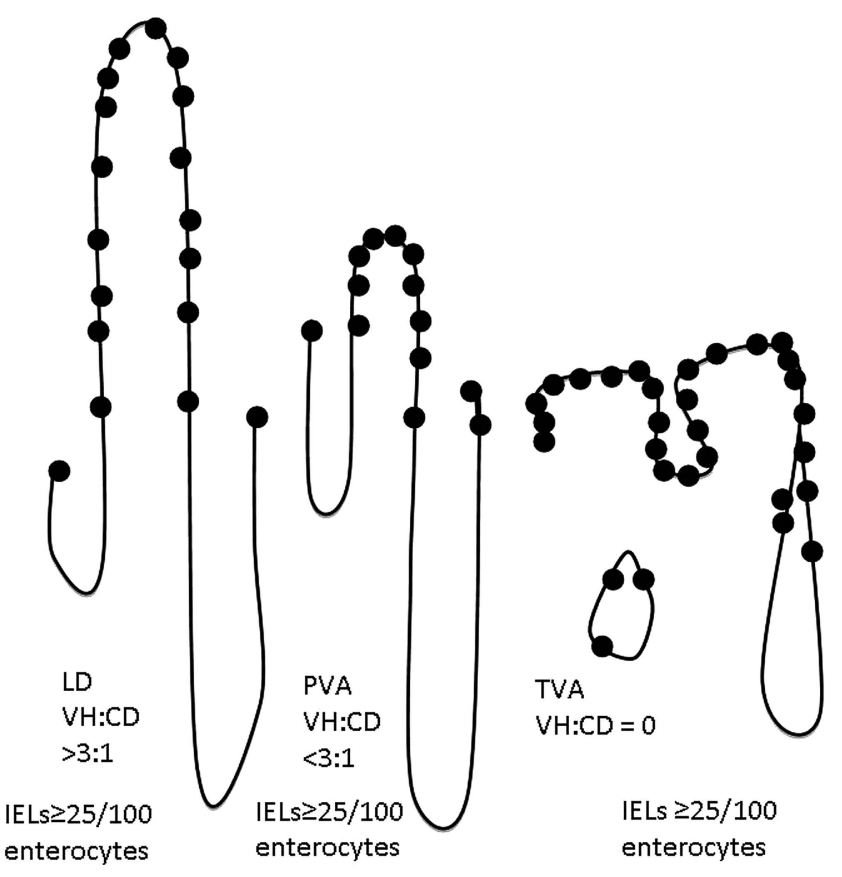


prediction of development of CD. However, this is currently experimental and the methodology requires tissue sections frozen in liquid nitrogen. ${ }^{124}$ Another diagnostic method meriting further evaluation is EmA assay in the culture medium of small intestinal biopsies. ${ }^{125}{ }^{126}$ Other investigators have reported their findings using new techniques associated with endoscopy to enhance the diagnosis of CD. These include confocal microscopy, high-resolution magnification endoscopy, optical band imaging ${ }^{127}$ and optimal coherence tomography. These novel techniques are still limited by availability, tolerability and cost. ${ }^{98}$ However, the immersion technique and dye enhancement in which the endoscopist instills water or a contrast dye (for example, indigo carmine or methylene blue) into the bowel lumen, with or without the assistance of magnification endoscopy, enhancing the visualisation of the villus ${ }^{128}$ can be readily used and improves visualisation of villi, thus increasing the sensitivity for detection of villous atrophy. ${ }^{98}$

\section{Dermatitis herpetiformis}

Dermatitis herpetiformis (DH) is the cutaneous manifestation of gluten-sensitive enteropathy precipitated by exposure to dietary gluten. ${ }^{129}$ It is characterised clinically by herpetiform clusters of intensely itchy urticated papules and small blisters distributed on the extensor aspects of the elbows and knees and over the buttocks and on the scalp. The commonest age of onset is between the third and fourth decade, though the condition may occur at any age after weaning. Male patients are affected twice as often as female patients. For the majority of patients the disease is lifelong with varying periods of activity, potentially due to varying degrees of dietary adherence.

The major diagnostic criterion for diagnosis is the presence of granular IgA deposits in the dermal papillae of uninvolved perilesional skin as shown by direct immunofluorescence, and the diagnosis should not be made unless this has been confirmed. ${ }^{130}$

Less than $10 \%$ of patients with $\mathrm{DH}$ have symptoms or signs of malabsorption but most have evidence of $\mathrm{CD}$ that responds to a GFD and relapses on gluten challenge. Patients with $\mathrm{DH}$ present with their skin manifestations and are not usually troubled by the underlying small bowel problem at the time of presentation. ${ }^{129} 131$ Abnormality of the small intestinal mucosa with either total or subtotal villous atrophy is found in approximately $70 \%$ of patients with $\mathrm{DH} .{ }^{132} \mathrm{~A}$ further $25 \%$ have normal villous architecture with increased IELs.

$\mathrm{DH}$ shares with $\mathrm{CD}$ an increased risk of developing lymphomas but this seems to be confined to those with severe gut involvement. The risk similarly declines with time on a strict GFD. ${ }^{133}$

Due to rash and itch, dapsone is often initiated. More than $70 \%$ of patients on a strict GFD are however able to slowly wean off dapsone over a period of 24 months. ${ }^{131}$

\section{FOLLOW-UP}

There is a paucity of data pertaining to adherence to a GFD being improved by follow-up in patients with CD. ${ }^{17}$ 134-138 Only one previous historical study has assessed the impact of regular follow-up (annual review) at a dedicated doctor-led coeliac clinic. ${ }^{136}$ The investigators suggested that adherence was improved by having access and regular follow-up within the setting of a specialist coeliac clinic (improvement in adherence was $97.5 \%$ for those under clinic follow-up vs $40.4 \%$ for those no longer under follow-up); however as this was an observational study and there were likely to be marked biases in referral of cases, it is not possible to be confident that the associations seen were causal. There are no published data assessing the value of this approach or whether adherence to a GFD, QoL, avoidance of complications, or satisfaction with the service is improved by offering a dietitian-led coeliac clinic. One of the key factors relating to adherence is dietetic input and regular follow-up. ${ }^{17} 134$ Optimally, the clinic should have gastrointestinal and dietetic expertise. ${ }^{139}$ Patients should be encouraged to join disease-specific patient support groups if applicable. ${ }^{140}$

Once the disease is stable and the patients manage their diet without any problems, annual follow-ups should be initiated. The physician should check on intact small intestinal absorption (full blood count, ferritin, ${ }^{32}$ serum folate, ${ }^{141}$ vitamin B12, ${ }^{142}$ calcium, ${ }^{143}$ alkaline phosphatase ${ }^{144}$ ), associated autoimmune conditions (thyroid-stimulating hormone and thyroid hormone(s), ${ }^{145}$ and serum glucose), ${ }^{146} 147$ liver disease (aspartate aminotransferase/alanine aminotransferase) ${ }^{40}$ and dietary adherence (anti-TG2 or EMA/DGP), although the sensitivity and specificity of the latter ${ }^{148} 149$ cannot substitute for structured dietary interview.

In follow-up of $\mathrm{CD}$, the key endpoints are normalisation of the health of patients judged by an absence of symptoms, and mucosal healing. ${ }^{17}$ A lack of symptoms ${ }^{72} 150151$ or negative serological markers are not reliable or responsive surrogates of mucosal response to diet. Dickey et al reported that among 32 patients with CD and persistent villous atrophy, EMA had normalised in 27 (84\%); while another British study found that 7/16 (44\%) individuals with persistent villous atrophy at follow-up biopsy had a normalised TTG. ${ }^{149}$ 152-154

The proportion of patients who do not achieve full histological recovery on diet varies, with most reports suggesting mucosal healing in 57-76\%. ${ }^{150} 155-159$

Some experts favour repeat intestinal biopsy after 1 year of dietary therapy; others, however, do not believe a repeat biopsy is essential for coeliac management in typical cases. It is universally acknowledged that there is little evidence to address whether clinical outcomes are significantly altered as a result of re-biopsy and that the cost-benefit analysis of such an approach has yet to be fully established.

\section{Recommendations}

- Follow-up biopsies may be considered in patients with $C D$, and are potentially helpful in identifying patients at increased risk of lymphoma. (Grade B)

- Follow-up biopsies are not mandatory if the patient with $C D$ is asymptomatic on a GFD, and has no other features that suggest an increased risk of complications. (Grade C)

- Follow-up biopsies should be undertaken in patients with $C D$ whose condition does not respond to a GFD. (Grade C)

\section{Assessing adherence to the GFD}

Whilst the panel of experts agree adherence to the GFD is most important for the health of a patient with $\mathrm{CD}$, there are no evidence-based grade A recommendations regarding the most useful way to assess this. Dietary adherence should guarantee mucosal healing and at least remission of most gastrointestinal symptoms. At present there are no non-invasive biomarkers that indicate complete mucosal recovery and a number of studies indicate a high prevalence of villous atrophy in adult patients with CD who appear to be adherent (see table 3). When specifically questioned, the experts agreed there is a difference between the first-year follow-up of a newly diagnosed patient and long-term follow-up of an adherent patient with stable disease. An adherent patient with stable disease needs less follow-up and testing than a patient with newly diagnosed CD 
Table 3 Histological recovery of duodenal mucosa in CD

\begin{tabular}{|c|c|c|c|c|c|c|c|c|c|c|}
\hline \multirow[b]{2}{*}{ Study } & \multirow[b]{2}{*}{ Country } & \multirow[b]{2}{*}{$\begin{array}{l}\text { Number of } \\
\text { patients }\end{array}$} & \multirow[b]{2}{*}{$\begin{array}{l}\text { Female } \\
\text { patients } \\
(\%)\end{array}$} & \multirow{2}{*}{$\begin{array}{l}\text { Median } \\
\text { (M)/average } \\
\text { (A) follow-up, } \\
\text { years }\end{array}$} & \multirow{2}{*}{$\begin{array}{l}\text { Positive } \\
\text { correlation } \\
\text { between dietary } \\
\text { adherence and } \\
\text { mucosal } \\
\text { improvement }\end{array}$} & \multirow[b]{2}{*}{$\begin{array}{l}\text { Symptoms } \\
\text { assessed }\end{array}$} & \multirow{2}{*}{$\begin{array}{l}\text { Main } \\
\text { reason for } \\
\text { mucosal } \\
\text { damage }\end{array}$} & \multicolumn{3}{|c|}{$\begin{array}{l}\text { Histological recovery } \\
\text { of duodenal mucosa }\end{array}$} \\
\hline & & & & & & & & Normal & Improved & $\begin{array}{l}\text { No } \\
\text { change/ } \\
\text { worse }\end{array}$ \\
\hline $\begin{array}{l}\text { Hutchinson } \\
\text { et al }{ }^{156}\end{array}$ & UK & 284 & 71 & $1.9(\mathrm{M})$ & $p=0.014$ & No & $\begin{array}{l}9 \% \text { poor } \\
\text { adherence }\end{array}$ & $35 \%$ & $40 \%$ & $20.10 \%$ \\
\hline $\begin{array}{l}\text { Rubio Tapia } \\
\text { et al }\end{array}$ & USA & 241 & 73 & $-^{*}$ & $p<0.01$ & Yes & $\begin{array}{l}\text { Poor } \\
\text { adherence/ } \\
\text { severe CD } \\
\text { at diagnosis }\end{array}$ & $\begin{array}{l}66 \% \\
\text { (5 years) }\end{array}$ & & $\begin{array}{l}19 \% \\
(2-5 \\
\text { years })\end{array}$ \\
\hline $\begin{array}{l}\text { Lanzini } \\
\text { et al }{ }^{159}\end{array}$ & Italy & 465 & $77 \dagger$ & $1.3(\mathrm{~A})$ & $p=0.029$ & Yes & $\begin{array}{l}25 \% \text { poor } \\
\text { adherence }\end{array}$ & $8 \%$ & $65 \%$ & $27 \%$ \\
\hline $\begin{array}{l}\text { Ciacci } \\
\text { et } a l^{158}\end{array}$ & Italy & 390 & 77 & $6.9(A)$ & $p<0.001$ & Yes & $\begin{array}{l}\text { Poor } \\
\text { adherence }\end{array}$ & $43.60 \%$ & $32.60 \%$ & \\
\hline $\begin{array}{l}\text { Wahab } \\
\text { et } a l^{160}\end{array}$ & $\begin{array}{l}\text { The } \\
\text { Netherlands }\end{array}$ & 158 & 72 & $1-2 \ddagger$ & No data & $\mathrm{NRCD}=$ symptoms & & $65 \%$ & & $\begin{array}{l}17.1 \% \\
\text { (5 years) }\end{array}$ \\
\hline $\begin{array}{l}\text { Kaukinen } \\
\text { (specific } \\
\text { study of } \\
\text { NRCD) }\end{array}$ & Finland & $\begin{array}{l}591 \\
13 \text { with } \\
\text { NRCD }\end{array}$ & $\begin{array}{l}69 \% \text { of } \\
\text { those } \\
\text { with } \\
\text { NRCD }\end{array}$ & $0.7(\mathrm{M}) \S$ & $p=0.02 t \dagger$ & $\begin{array}{l}\text { Became } \\
\text { symptomatic if } \\
\text { NRCD }\end{array}$ & $\begin{array}{l}46 \% \text { poor } \\
\text { adherence }\end{array}$ & & & $1.90 \%$ \\
\hline Tuire et $a l^{72}$ & Finland & 177 & 73 & 7-109 & No correlation** & $\begin{array}{l}\text { Patients } \\
\text { asymptomatic } \\
\text { Clinical relevance of } \\
\text { persistent IELs with } \\
\text { normal villi }\end{array}$ & & & $85 \%$ & \\
\hline $\begin{array}{l}\text { Lebwohl } \\
\text { et } a l^{155}\end{array}$ & Sweden & 7648 & 63 & $1.3(\mathrm{M})$ & No data & no & No data & $57 \%$ & $43 \%$ & \\
\hline \multicolumn{11}{|c|}{ 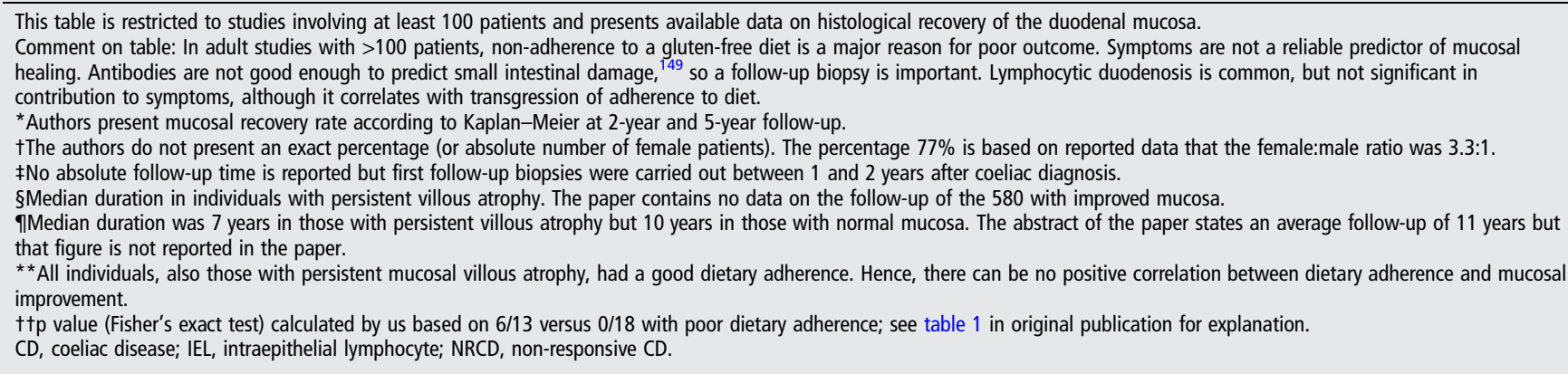 } \\
\hline
\end{tabular}

in whom the GFD has just commenced, and neither the mucosa nor biochemical aberrations have yet normalised.

There are four steps to assess dietary adherence: clinical assessment of symptoms, dietetic review, serum antibodies and follow-up biopsy.

\section{Symptoms}

A meta-analysis of seven studies including more than 3000 subjects showed that the presence of gastrointestinal IBS-like symptoms is common in CD. IBS-type symptoms are more common in patients with CD who are not adherent to a GFD (OR 2.69; 95\% CI 0.75 to 9.56). ${ }^{161}$ However, patients with CD who are also adherent to a GFD are more likely to experience (persistent) symptoms than controls. ${ }^{161}$

\section{Dietetic review}

The second step is a careful dietetic review conducted by a dietitian or dedicated physician. Apart from a visual analogue score scale which consists of an unmarked line with the anchor sentences 'I never adhere to my diet' and 'I always adhere to my diet' at each end, ${ }^{162}$ there are a number of questionnaires evaluating selfreported GFD adherence and food frequency in the English language $^{163-166}$ that are also available in other languages. ${ }^{167-171}$
These questionnaires should be augmented by a dietetic review, which is a useful tool to tease out inadvertent gluten intake and to provide education for a balanced and adequate nutrient intake. There is no standard or quality control for dietetic review because local diets and habits require a specific structured interview, which is related to the quality of the diet. Currently, no data are available on GFD review outcomes in different countries, and there is no evidence that a careful review can substitute for other tools (eg, biopsy) to predict mucosal damage.

Studies report that poor dietary adherence due to occasional lapses is frequent and it is influenced by a number of factors, such as age at diagnosis, knowledge of disease and psychological factors. ${ }^{172} 173$

\section{Serology}

The third step in the first year is to check the IgA-TG2 or appropriate serology. Despite contradictory results, ${ }^{148} 149$ it is reasonable to assume that positive antibody titres correspond to some gluten intake and there is also some evidence that low TTG titres do not accurately predict mucosal recovery. ${ }^{148} 149$ Tursi et $a l^{148}$ reported that out of 17 patients with persistent villous atrophy 1 year after diagnosis, only 1 (6\%) was anti-TG2positive and 3 (18\%) EMA-positive. Vahedi et al ${ }^{149}$ reported a 
substantially higher sensitivity for persistent total villous atrophy (73\% and 91\% for IgA-TG2 and EMA, respectively), but reported no data for partial villous atrophy.

\section{Follow-up biopsy}

The last step is the follow-up biopsy. Some authors suggested that it is important to perform a duodenal biopsy to assess the recovery of intestinal mucosa and to exclude RCD and malignancies. However, one recent study of 7648 individuals failed to show that overall mortality was increased in patients with CD with persistent villous atrophy at follow-up biopsy in patients with a median follow-up of more than 11 years. ${ }^{174}$

In many cases 1 year is too brief a timespan to obtain complete recovery of duodenal mucosa. Tuire et $a l^{72}$ found that IELs were more frequent even 2-5 years after coeliac diagnosis compared with thereafter. Some experts do not routinely perform a follow-up biopsy in asymptomatic patients with negative serology and good adherence. Currently there are no studies indicating an absolute necessity of follow-up biopsy for all patients, but of eight major studies, five $\begin{array}{lllll}150 & 151 & 159 & 160 & 175\end{array}$ examined follow-up biopsies at roughly 2-5 years (table 3 ). This may be related to costs (economic and psychological) of performing a procedure that in theory should be repeated many times over the years of follow-up as dietary adherence may vary over time.

The authors of this review underline the necessity of distinguishing asymptomatic patients in whom clinical improvement, negative serology, and potentially a follow-up biopsy and good adherence assessed by dietetic review are considered sufficient from symptomatic patients in whom repeated biopsies are needed to rule out RCD or malignancies. Studies report that poor dietary adherence due to occasional lapses is frequent and it is influenced by a number of factors, such as age at diagnosis, knowledge of disease and psychological factors. ${ }^{172} 173$

\section{Histological recovery of duodenal mucosa in adult patients with CD}

In adults, neither symptoms ${ }^{72} 150151156{ }^{158-160}$ nor serology ${ }^{149}$ is reliable to predict small intestinal damage; ${ }^{149}$ assessing mucosal healing by biopsy is the key. Serum antibodies have poor sensitivity for persistent villous atrophy, especially 1 year or more after diagnosis and institution of a GFD.

Lymphocytic duodenosis is commonly seen on biopsy of follow-up patients. It is rarely symptomatic, although it may also correlate with transgression of adherence from the GFD. ${ }^{72}$ Early biopsy (at 6 months) is not considered to be optimal. ${ }^{156}$

\section{Recommendations}

- When adherence is questioned, it should be reviewed by a dietitian. (Grade C)

- Symptomatic patients should be evaluated more thoroughly than asymptomatic patients. (Grade C)

\section{Gluten challenge}

To perform a gluten challenge, a recent study recommends a 14-day gluten intake at $\geq 3 \mathrm{~g}$ of gluten/day (two slices of wheat bread per day) to induce histological and serological changes in the majority of adults with CD. ${ }^{176}$ The challenge can be prolonged to 8 weeks if serology remains negative at 2 weeks (in the Leffler $e t a l^{176}$ study, serology was negative after 2 weeks in all cases, but positive after another 2 weeks).

\section{Medical management during follow-up}

Long-term follow-up can be in secondary care clinics or in primary care as long as the expertise is available. ${ }^{177}$ However, prompt access to specialist centres or secondary care is recommended if any problems arise, and it should be noted that the need for long-term follow-up is controversial. ${ }^{17} 178$

The risk of osteoporosis ${ }^{144} 1^{179-183}$ and bone fracture ${ }^{184-190}$ is increased with $\mathrm{CD},{ }^{2}$ with one Swedish study showing an excess risk of any fracture of 481/100 000 person-years in adults with $\mathrm{CD}^{189}$ and a British study (13\% of individuals were children) $320 / 100000$ person-years. ${ }^{184}$ The excess risk is reduced with good dietary adherence and reduction in intestinal villous atrophy, and bone density increases during the first year of GFD adherence. ${ }^{191-195}$ However, one population-based study found a similar excess risk for fractures before and after coeliac diagnosis (eg, the incidence ratio 5-10 years before CD diagnosis was 1.8 compared with 2.2 some 5-10 years after diagnosis). ${ }^{189}$

On the basis of current evidence, the suggestion should therefore be to measure calcium, alkaline phosphatase and vitamin D levels (and parathyroid hormone for compensatory increase) at diagnosis and replace as necessary. Calcium intake should be maintained at or above $1000 \mathrm{mg}$ per day. ${ }^{196}$ Bone density should be measured in those at high risk of osteoporosis; appropriate criteria for judging this are given by the BSG (http://www. bsg.org.uk/images/stories/clinical/ost_coe_ibd.pdf). Repeat bone density investigations (generally after an interval of $\geq 2$ years) should otherwise be considered in patients who have low bone density on index measurement following initiation of appropriate treatment, or who have evidence of ongoing villous atrophy or poor dietary adherence. Postmenopausal women with CD may require supplementation in addition to the GFD. ${ }^{197}$ Loss of bone density at a greater than expected rate should prompt measurement of vitamin D levels, dietary review of adherence, consideration of repeat intestinal mucosal biopsy and review of additional risk factors such as hypogonadism.

Hyposplenism ${ }^{198}$ associated with CD may result in impaired immunity to encapsulated bacteria, and an increase in such infections has been demonstrated in CD. ${ }^{199-201}$ Hyposplenism does not seem to correlate with duration of GFD. ${ }^{198}$ Vaccination against Pneumococcus is therefore recommended. ${ }^{202}$ However, it is unclear whether vaccination with the conjugated vaccine is preferable in this setting and whether additional vaccination against Haemophilus, Meningococcus and Influenza ${ }^{203}$ should be considered if not previously given. ${ }^{204}$ It should also be noted that patients with $\mathrm{CD}$ may have a weaker response to hepatitis $\mathrm{B}$ vaccination than normal. ${ }^{205} 206$

\section{Recommendations}

- Newly diagnosed patients should have vaccination for Pneumococcus. (Grade C)

- Bone density should be measured after 1 year of diet in patients who have additional risk factors for osteoporosis or if over the age of 55 years. (Grade D)

- Adult patients with CD should have a calcium intake of at least $1000 \mathrm{mg}$ per day. (Grade D)

- Patients with CD require follow-up by a dietitian and/or clinician with an interest or expertise in this field. (Grade D)

- Patients should have annual haematological and biochemical profiles. (Grade D)

- A GFD is the core management strategy for prevention of osteoporosis. (Grade D) 
Table 4 CD as a candidate for general population screening

\begin{tabular}{|c|c|}
\hline WHO criteria & Comment \\
\hline That the disease is common and well defined & $\begin{array}{l}\text { CD occurs in approximately } 1 \% \text { of the western population, }{ }^{24111} \text { and is even more frequent in selected } \\
\text { populations. }^{207} 208\end{array}$ \\
\hline Screening tests are simple, safe and accurate & $\begin{array}{l}\text { IgA-TG2 screening offers high sensitivity and specificity but the positive predictive value does not attain } 100 \% \text {, } \\
\text { with a consequent risk of false-positive cases. }{ }^{92} 209\end{array}$ \\
\hline The screening test should be culturally acceptable & Screening seems to be culturally accepted in most parts of the world \\
\hline Treatment is available & GFD offers symptomatic relief and will often lead to mucosal healing. \\
\hline Clinical detection is difficult & $\begin{array}{l}\text { The clinical picture of CD varies, and many patients only have minor symptoms, }{ }^{31208210} \text { making it difficult to } \\
\text { diagnose CD. }\end{array}$ \\
\hline $\begin{array}{l}\text { If undiagnosed and untreated the disease will lead } \\
\text { to severe complications }\end{array}$ & $\begin{array}{l}\text { The only available treatment is a GFD. The GFD seems to reduce symptoms and the risk of complications in } \\
\text { symptomatic patients, }{ }^{211-213} \text { but it is doubtful whether the GFD leads to health gains in asymptomatic } \\
\text { patients, }{ }^{81} 214-218219 \\
\text { fact have symptoms. }{ }^{216} \text { It is also unclear if QoL in patients with screen-detected asymptomatic CD is } \\
\text { different }{ }^{81} 214217220-223 \text { from that of the control populations. Without a decrease in pre-diagnostic QoL, institution of } \\
\text { a GFD is unlikely to result in improved QoL after diagnosis. }\end{array}$ \\
\hline Testing and treatment is cost effective & $\begin{array}{l}\text { Cost effectiveness depends on the duration of symptoms and the risk of complications in untreated versus treated CD. } \\
\text { It is still not clear if the risk of complications is substantially lower in diagnosed CD than in undiagnosed CD. }\end{array}$ \\
\hline
\end{tabular}

\section{SCREENING FOR CD}

Table 4 lists the WHO criteria for general population screening. CD fulfils many of these criteria but not all of them as yet. Our recommendation is active case finding but not mass screening. Given that $\mathrm{CD}$ is a common disease (about $1 \%$ of the western population ${ }^{22}{ }^{24}$ ) and that there is a therapy (GFD) that most often relieves symptoms, and may even have an effect on the risk of future complications, any patient with signs or symptoms of CD should undergo testing.

In addition, testing should be carried out in high-risk groups such as those with iron deficiency anaemia, ${ }^{224}$ Down's syndrome, ${ }^{225}$ type 1 diabetes mellitus, ${ }^{147}$ osteoporosis ${ }^{184} 189226$ and IBS when CD is suspected. The coeliac prevalence in these groups typically varies between $2 \%$ and 5\%. ${ }^{144} 227228$

\section{Recommendations}

- There is insufficient evidence to recommend population screening for $C D$, however there should be a low threshold for case finding in clinical practice as per National Institute for Health and Care Excellence guidelines. ${ }^{3}$ (Grade B)

- Symptomatic first-degree relatives of patients with CD should undergo CD testing. (Grade C)

\section{QUALITY OF LIFE}

There has been a growing interest in how patients with CD perceive the impact of their diagnosis, how their psychological state is influenced by the disease and the effect of GFD. Several studies report that patients with CD have lower QoL scores than the general population. ${ }^{229-232}$

Though some studies have found improved QoL with GFD treatment in symptomatic and screening-detected patients, 222233 others suggest that any benefit of diet is restricted to those presenting with symptomatic disease. ${ }^{214} 220221$ Since mood disorders such as anxiety, depression and fatigue are often linked with $\mathrm{CD}$, before and after diagnosis, it is likely that they may contribute to the effect upon QoL. A recent meta-analysis ${ }^{234}$ suggested that depression, but not anxiety, is more common in adults with CD. Also fatigue has been linked to undetected $\mathrm{CD}{ }^{235}$

\section{GLUTEN-FREE DIET}

The mainstay of treatment of CD and DH is a GFD. The term gluten should be used to indicate not only wheat-based proteins (gliadins), but it also includes those from barley (hordeins) and rye (secalins), and cereal hybrids such as triticale. ${ }^{236}$ Originally oats were also avoided in the GFD. Earlier research indicates that oats uncontaminated by gluten are probably safe for patients with CD. ${ }^{237} 238$ This is important because oats contain soluble fibre, are able to lower blood glucose and attenuate insulin response. ${ }^{239}$ The appearance of symptoms related to introducing oats might be due to cross contamination. Also a small percentage of patients with CD may be sensitive to oats ${ }^{240}$ and develop symptoms or even mucosal damage. ${ }^{241} 242$ Patients with CD should be educated to avoid cereals and food containing gluten (breakfast cereals, flours, pasta, cakes, biscuits, sauces etc) derived from wheat, barley or rye and food made from gluten-contaminated oats, and encouraged to eat naturally occurring gluten-free foods and alternative sources of starch (corn, rice, potatoes etc). Levels of susceptibility to gluten contamination of food vary among patients with CD. Although it has also been suggested that the acceptable threshold for gluten content in gluten-free products can from the clinical point of view be set at $100 \mathrm{ppm}(1 / 4 \mathrm{mg} / \mathrm{kg}),{ }^{243}$ the Codex Alimentarius Commission of the WHO issued new guidelines for gluten content of processed food in 2008 and a law from the European Commission (EC41/2009), effective since January 2012, stipulated that foods labelled as 'gluten free' should contain $\leq 20$ parts per million of gluten, and that this gluten content is safe for the coeliac population. The $20 \mathrm{ppm}$ threshold for gluten-free food is also accepted by the US Food and Drug Administration, effective since August 2013. Newly diagnosed patients should be referred to a dietitian to discuss dietary management. ${ }^{243}$ It is important that they are educated not only to avoid gluten but also to have a sufficient intake of nutrients, vitamins, fibre and calcium present in their GFD. ${ }^{244}$ Recent data also indicate that a strict GFD might be of help in reaching ideal body weight, whether an individual is underweight or obese at diagnosis. ${ }^{24}$ Data suggest that adherence to the GFD is better achieved when the patient is well educated and supported by carers and families. However, there is a wide variation in provision of dietary consultation services for patients diagnosed with $\mathrm{CD}$ in the world. A survey indicates that dietetic support may be underprovided in the UK. ${ }^{246}$ 


\section{Safe gluten intake?}

As shown previously, diagnosis and advice on a gluten-free diet often lead to mucosal recovery, while poor adherence to diet slows or hinders complete recovery.

Whilst contamination of the diet by gluten may be unavoidable and increased IEL counts are associated with less severe nutritional and metabolic consequences than classic CD with villous atrophy, patients may have significant signs and symptoms related to this disorder. A clinical response and mucosal recovery can be achieved by strict adherence to a gluten-free diet. On balance, data support treatment of patients with $C D$ regardless of the degree of mucosal damage. ${ }^{247}$

A recent review on 'safe' gluten levels argues that daily intakes of $<10 \mathrm{mg}$ have no effect on mucosal histology, ${ }^{248}$ whereas definite alterations are caused by a daily intake of $500 \mathrm{mg}$ and observable alterations by $100 \mathrm{mg}$. A calculated daily intake of $30 \mathrm{mg}$ seems not to harm the mucosa. Therefore, at present, a safe limit could be set between 10 and $100 \mathrm{mg} .{ }^{249}$ The most comprehensive systematic review (35 studies) suggests that while the amount of tolerable gluten varies among people with $\mathrm{CD}$, a daily gluten intake of $<10 \mathrm{mg}$ is unlikely to cause significant histological abnormalities. ${ }^{248}$

There is extensive research on GFD and how this may influence the clinical course. While a recent study of more than 7000 individuals undergoing follow-up biopsy found no association between persistent villous atrophy (likely to signal poorer dietary adherence) and overall mortality, ${ }^{174}$ this does not rule out that poor dietary adherence is negative for specific health outcome, such as autoimmune disease, ${ }^{250} 251$ pregnancy outcome (two studies have found poor foetal outcome in pregnant women with undiagnosed $\mathrm{CD}$ but not in diagnosed $C D^{41}{ }^{252}$ ), and especially the risk of lymphoma. Most studies on lymphoma risk according to dietary adherence point towards a protective effect from GFD but the studies have so far been small in size, ${ }^{212}{ }^{253-255}$ preventing firm conclusions. However, recently Lebwohl et $a l^{175}$ found a statistically significantly increased risk of lymphoma in patients with $\mathrm{CD}$ with persistent villous atrophy compared with those with mucosal healing.

A frequent complaint of patients with $\mathrm{CD}$ is that they experience limitations in their social life because of difficulty accessing glutenfree meals or concern about the safety of food when eating out. The patients' worries are justified as a survey shows that chefs' knowledge about $\mathrm{CD}$ is lower than that of the general public. ${ }^{256}$ Therefore, education about a GFD needs to be directed to catering personnel. Another criticism is that the availability of gluten-free food is clearly limited in more rural areas and shopping for glutenfree food is time consuming. In most countries, high-quality glutenfree products are available in supermarkets or in special health food stores and on the internet, but the cost of gluten-free food is much greater than the equivalent wheat-based foods. ${ }^{257} 258$

\section{Recommendations}

- Patients should adhere to a GFD and have an intake of less than $10 \mathrm{mg}$ gluten per day. (Grade B)

- Gluten challenge is not recommended in the ordinary patient with $C D$, but in patients in whom the diagnosis remains unclear despite a follow-up biopsy, gluten challenge should be performed. (Grade C)

- Patients may commence gluten-free oats at diagnosis. (Grade D)

- A GFD is recommended to decrease the excess risk of adverse foetal outcome and of lymphoma among patients with CD. (Grade C)

\section{Patient information and support}

Patient support should not be a monologue by a physician, but instead a two-way communication involving the patient, and his/ her family. Ideally, collaboration between the patient, the patient's family, an expert dietitian and interested physician should be the setting in which the GFD should be initiated. Family involvement is very important as the disease (including GFD) will inevitably affect family members, but also joining a national coeliac support group can help patients cope with their disease.

Patients need information, reassurance and the opportunity to learn at their pace about the rather challenging demands of a GFD. They particularly need to be encouraged and motivated to adapt to and maintain a GFD. Continued professional engagement in their follow-up care is likely to help sustain that motivation. Unfortunately, many patients report that they are not satisfied with the amount and quality of the information offered by their physician. ${ }^{216}$ Physicians should inform patients even before the $\mathrm{CD}$ diagnosis, offering information about serological testing, and what it means to undergo a small intestinal biopsy. Worries are common in patients awaiting a biopsy 259 and the physician should address this anxiety.

Patients may want information about when and where CD occurs, its aetiology and whether it is a common disease or not. Understanding the vital role of GFD in the management of CD is important for dietary adherence. ${ }^{140}$ Attaining dietary adherence may be particularly difficult in patients identified through screening. Patients with CD often report reduced QoL because of dietetic restrictions and this must be taken into account. ${ }^{260-263}$ Part of the reduced QoL may be due to social restrictions, such as not being able to eat out with friends, and the economic burden from the more expensive GFD..$^{258} 264$ Patients should also be informed that while most symptoms are likely to go away on a GFD, some symptoms may persist (see section on 'Non-responsive CD').

\section{Recommendation}

- At diagnosis, patients should be encouraged to join their national coeliac support group. In the UK, patients should be advised about gluten-free items on prescription (FP10), details of which are available from http://www.coeliac.org.uk.

\section{Non-responsive CD}

After adoption of the GFD, 4-30\% of patients with CD report persisting symptoms and are considered to be affected by nonresponsive $\mathrm{CD}(\mathrm{NRCD}) .{ }^{265}$ Once the initial diagnosis of $\mathrm{CD}$ has been confirmed, adherence to the GFD should be assessed by an expert dietitian as inadvertent or deliberate gluten exposure is the most frequent cause of NRCD. ${ }^{265} 266$

After these initial steps, evaluation should be individualised; however assessment for ongoing enteropathy plays a central role, therefore a follow-up biopsy is needed. Small bowel imaging should be performed in any patient with abdominal pain, persisting fever, obstruction, anaemia, gastrointestinal bleeding or unexplained weight loss. ${ }^{267}$ If duodenal biopsy does not reveal a persistent enteropathy, symptoms are likely to be due to a second condition. ${ }^{265} 268$

While the GFD is efficacious at controlling the signs and symptoms of $\mathrm{CD}$ and improving intestinal histology in most patients, treatment of $\mathrm{CD}$ is currently imperfect. Over time, virtually all individuals with $\mathrm{CD}$ will have symptomatic exacerbations due to gluten exposure and up to $30 \%$ of patients will 
Figure 2 Investigation of the patient with non-responsive coeliac disease (NRCD). Based on a figure by Mooney et al. $^{305}$ FODMAPs, fermentable oligosaccharides, disaccharides, monosaccharides, and polyols; $\mathrm{Gl}$, gastrointestinal; HLA, human leucocyte antigen; RCD, refractory coeliac disease; SIBO, small intestine bacterial overgrowth.

\section{NRCD}

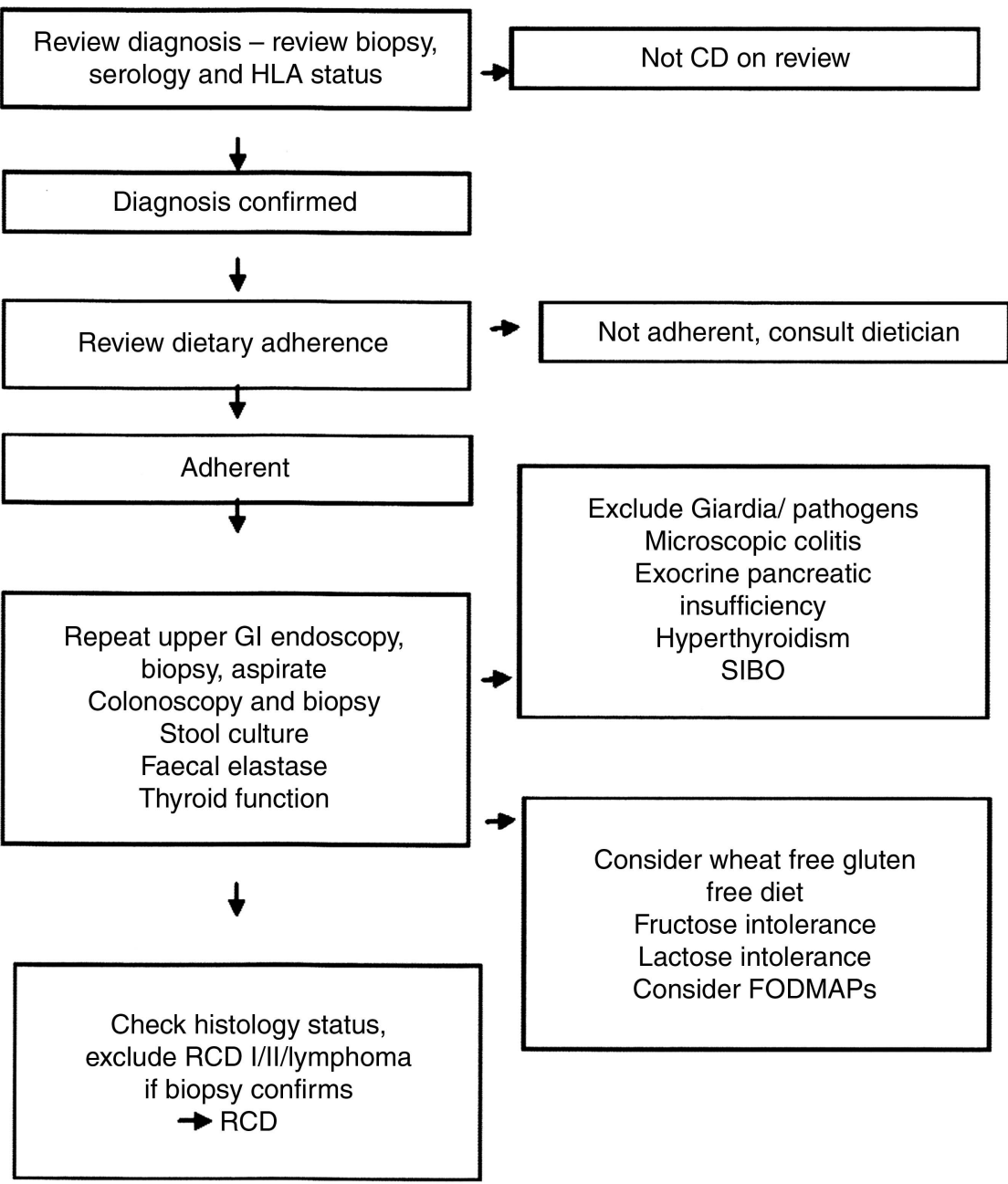

have symptoms severe or chronic enough to visit their treating physician $^{265} 266$

Comprehensive monitoring of patients with $\mathrm{CD}$ requires assessment for NRCD and efficient evaluation for potential aetiologies. NRCD may be considered in three categories. ${ }^{265} 266269$ First and most commonly, NRCD is due to continued dietary exposure to gluten. ${ }^{265} 266269$ Second, it may be due to a preexisting or coincidental condition causing symptoms that resemble CD which may have led to the detection of otherwise asymptomatic $\mathrm{CD}$-this includes $\mathrm{IBS}^{33}$ or colonic malignancy causing anaemia. ${ }^{270}$ Finally, it may be due to conditions associated with $\mathrm{CD},{ }^{268}$ such as secondary lactose intolerance, ${ }^{265}$ pancreatic exocrine insufficiency, ${ }^{271}$ small bowel bacterial overgrowth, microscopic colitis ${ }^{272}$ and cow's milk protein sensitivity.

Very occasionally a state refractory to gluten withdrawal occurs, referred to as RCD. Figure 2 suggests an outline for investigating patients with NRCD.

In symptomatic patients with ongoing enteropathy and RCD, coeliac-related malignancies and disorders that mimic CD (table 2) must be excluded. RCD is defined as persistent or recurrent malabsorptive symptoms and/or signs with villous atrophy despite a strict GFD for more than 12 months in the absence of other causes of villous atrophy or malignant complications and after confirmation of $\mathrm{CD} .^{7} \mathrm{RCD}$ is subdivided into type I
(RCDI) and type II (RCDII). The most important aspect of differentiating RCDI and RCDII is demonstration of a monoclonal population of $\mathrm{T}$ cells or aberrant $\mathrm{T}$ cells in the latter. There are different methods available for this, including genetic analysis of T-cell receptor clonality, immunohistochemistry and flow cytometry. Most laboratories will employ at least two methods but their relative contributions remain uncertain. Currently there is variation in the criteria used to diagnose RCDII. The two factors that support the diagnosis of RCDII include loss of normal surface markers CD3 and CD8 with preserved expression of intracytoplasmic CD3 and detection of monoclonal rearrangement of T-cell receptor chain. ${ }^{120}$ Areas of uncertainty include the use of immunohistochemistry versus flow cytometry for IEL classification and the relative prognosis of patients with discordant IEL and T-cell studies.

Patients with normal CD3 and CD8 expression and no evidence of T-cell monoclonality have RCDI with a good prognosis. Patients with RCDII have a poorer prognosis, due predominantly to nutritional complications and transformation into enteropathy-associated T-cell lymphoma (EATL). ${ }^{273} 274$ Ulcerative jejunoileitis (UJI) is a rare condition characterised by inflammatory ulceration of the small bowel that arises in RCD. ${ }^{274-276}$ The finding of UJI should raise suspicion for lymphoma. 
There is no standard treatment for RCD. Elemental diets, systemic steroids, oral budesonide, oral thioguanines including azathioprine are used in RCDI (and sometimes are beneficial), but have limited benefit in RCDII. ${ }^{277} 278$ In RCDII, cyclosporine, cladribine and high-dose chemotherapy with autologous stem cell support have been reported; however, therapy must be individualised and include surveillance for EATL. ${ }^{120}$

EATL is a rare lymphoma strongly associated with RCDII, ${ }^{273}$ which carries a poor prognosis with a cumulative 5-year survival of less than $20 \% .^{279}{ }^{280}$ Currently, two groups of EATL are recognised $^{281}$ : EATL type I accounts for $80-90 \%$ of all cases and is a large cell lymphoma exclusively associated with $\mathrm{CD} .{ }^{282} \mathrm{In}$ contrast, EATL type II has not been associated with CD. ${ }^{281} 283$

The poor prognosis of EATL is determined by extent of disease at diagnosis, multifocal small bowel involvement, poor general health and presence of complications including perforation that preclude chemotherapy. ${ }^{120}$ Presence of RCDII is associated with a poor prognosis compared with isolated EATL in CD without RCDII. There is no proven effective treatment in RCDII, though a number of strategies have been proposed, and patients should be referred to a tertiary centre to optimise their management.

Finally, numerous studies have confirmed the association between CD and B-cell lymphoma ${ }^{284-286}$ and CD and small intestinal adenocarcinoma. $42254287-289$

\section{Recommendations}

- Patients with persistent symptoms despite a GFD should have a follow-up biopsy. (Grade B)

- In symptomatic patients with ongoing enteropathy and RCD, coeliac-related malignancies and disorders that mimic CD must be excluded. (Grade C)

- Small bowel imaging should be performed in any patient with abdominal pain, fever, obstruction, anaemia, gastrointestinal bleeding or unexplained weight loss. (Grade D)

- Patients with RCD should be referred to a tertiary centre to optimise their management. (Grade D)

\section{NOVEL TREATMENT}

The role of non-dietary therapies-as an adjunct or as an alternative to the GFD- has yet to be ascertained. Of the candidate approaches, immunotherapy (including hookworm exposure $)^{290291}$ is currently explored as an alternative to GFD but, even if successful, is unlikely to benefit all patients. The role of glutenases (propyl endopeptidases) and tight junction regulators (table 5) are likely to be in reducing the threshold response and optimising the benefits of gluten restriction rather than allowing a normal gluten-containing diet.

Table 5 contains a list of potential novel treatments. None of the available novel treatments can as yet (January 2014) be recommended for use outside clinical trials.

\section{Recommendation}

- None of the available novel treatments can as yet be recommended for use outside clinical trials. (Grade D)

\section{DISCUSSION}

We recommend testing for CD in those with suggested symptoms or syndromes, especially if they have a first-degree relative with CD. ${ }^{53}$ There is not yet sufficient evidence to support indiscriminate general population screening. Specific serology such as IgA-TG2 and IgG-DGP with or without a strategy for determination of total IgA level should be the preferred serologic strategy for detection of CD. Ideally a combination of serology and biopsies done on a gluten-containing diet will then provide the most robust diagnosis of CD. Additional testing may be necessary for those with less than clear-cut results.

We recommend a duodenal biopsy before the diagnosis of CD. This contrasts with the recent ESPGHAN recommendations where a duodenal biopsy is optional in symptomatic paediatric patients in whom the IgA-TG2 level exceeds 10 times the upper limit of normal, EMA antibodies are positive on a separately taken blood sample and HLA typing is positive for DQ2 or DQ8. ${ }^{1} \mathrm{CD}$ has been linked to a large number of symptoms (table 1 in the ESPGHAN review on paediatric CD lists 16 such

Table 5 Novel treatment in CD

\begin{tabular}{|c|c|}
\hline Treatment & Comment \\
\hline Cereal genomics & $\begin{array}{l}\text { The high copy numbers in gliadin genes have so far limited attempts to genetically modify cultivars ince } \\
\text { expressing immunotoxic peptides }{ }^{292} \\
\text { RNA interference of protein translation may reduce gliadin expression, with evidence of reduced prolifer } \\
\text { lymphocytes challenged in vitro } 293\end{array}$ \\
\hline Prolyl endopeptidases (PEPs) & $\begin{array}{l}\text { These endopeptidases have been isolated from microbial sources and may be capable of enzymatic clea } \\
\text { immunotoxic gluten peptides ex vivo. }{ }^{294} 295296 \text { A combination of a glutamine-specific endoprotease (EF } \\
\text { and a prolyl endopeptidase (subcutaneous PEP from Sphingomonas capsulata) } \text { ) }^{297} \text { acts synergistically an } \\
\text { evaluated in a } 6 \text {-week phase IIA clinical trial against } 2 \mathrm{~g} \text { gluten taken daily }\end{array}$ \\
\hline Larazotide acetate & $\begin{array}{l}\text { Larazotide is a tight junction regulator }{ }^{299} \text { and maintains intestinal barrier function after gluten challeng } \\
\text { IIA clinical trials have demonstrated limited effects on intestinal permeability after gluten ingestion, but } \\
\text { on symptoms and signs. }{ }^{301}\end{array}$ \\
\hline TG2 inhibitors & $\begin{array}{l}\text { Candidate peptidomimetic blockers are currently entering clinical trials but no data are available yet. }{ }^{302} \\
\text { limitation of this drug candidate is that TG2 activity occurs in a number of diseases and a TG2 inhibitor } \\
\text { have unwanted side effects }\end{array}$ \\
\hline $\begin{array}{l}\text { Blocking of the antigen presenting groove of } \\
\text { HLA-DQ molecules }\end{array}$ & No trials yet. Regarded as unpredictable \\
\hline $\begin{array}{l}\text { Subcutaneous injection of dominant immunotoxic } \\
\text { gliadin peptides }{ }^{65}\end{array}$ & $\begin{array}{l}\text { Stimulates an immunoregulatory T-cell response or deplete or anergise antigen specific memory T cells. } \\
\text { Responses would be specific to the HLA haplotype DQ2 or } 8 \text {. Ongoing phase II trials. }\end{array}$ \\
\hline Polymer binding agents ${ }^{303}$ & No clinical trials performed yet \\
\hline
\end{tabular}


symptoms and signs with additional symptoms in the text). ${ }^{1}$ There is a risk that all symptoms, independent of their origin, may be taken as a sign of CD when the sensitivity and specificity of even gastrointestinal symptoms are moderate in CD. ${ }^{304}$ Other reasons to require a small intestinal biopsy prior to diagnosis is that not all commercial IgA-TG2 kits are of high quality, ${ }^{78}$ and that alternative diagnoses may be more common, and sometimes serious, in adults with suspected CD. Finally, an initial biopsy is important for the follow-up of patients, especially those whose condition is non-responsive to a GFD.

Adequate (more than four) biopsies should be taken, from the distal duodenum and the duodenal bulb to maximise diagnosis. The threshold for abnormal IELs is $\geq 25 / 100$ enterocytes, but for a definite diagnosis villous atrophy is required. However, lesser degrees of damage ( $\geq 25$ IELs but no villous atrophy) combined with positive serology (IgA-EMA, TTG or IgG-DGP) may also represent CD ('probable CD'),

The treatment of CD is a lifelong and strict GFD. The goal of treatment is to relieve symptoms, achieve mucosal healing, avoid complications of CD, and have a good QoL with a nutritionally complete GFD. This is best achieved when patients are motivated and receive expert information in a collaborative way, with resources including expert dietitians and interested medical care. Follow-up of CD is needed to ensure response to symptoms, prevention of consequences, and continued maintenance of motivation to remain gluten free.

Discussions upon the issue of repeating duodenal biopsies were intense in our group. There is no conclusive evidence of the benefit of universal follow-up biopsy, and we were unable to reach a consensus. Some would undertake follow-up biopsies in all patients with CD after 2-5 years on a GFD (table 3 ). There are others who reserve follow-up biopsies for those in whom there are persistent and recurrent symptoms or those for whom the follow-up biopsies are necessary to help confirm the diagnosis in the setting of continued diagnostic uncertainty.

There are novel techniques that may enhance the sensitivity of endoscopic examination, of which the immersion technique is probably the most feasible currently. An understanding of the precise value of various serologic strategies in the detection of $\mathrm{CD}$ is continuing to evolve, as are advances in therapies that may ultimately provide some mitigation of the impairment of the QoL that is inherent in a strict GFD.

Ultimately, this review should not be regarded as fixed. Instead it represents our understanding of what is best in adult CD management according to current knowledge. It is likely, and indeed we hope, that there will be substantial progress in diagnosis, evaluation and management of CD to reduce the burden on the patient and society. We anticipate that future updated versions of these guidelines will be based on evolving published literature that may have an audit or research base relevant to adult CD. Data in this review were mostly retrieved through searches of PubMed. We acknowledge that there are other medical databases and we cannot rule out that had we searched more than one database we may have identified additional relevant studies that have now been left out of this review.

\section{Areas for future research}

The panel of experts recognise that the main challenge in the future is to allocate available resources effectively to reduce the burden of disease from CD.

Future research should focus on the following areas:

- how to induce long-term remission without a GFD, that is, novel therapies and vaccine;

- better understanding of the disease processes, including genetics and antigen presentation;
- prevent and cure extra-intestinal manifestation and complications, including infections;

- be able to assess tolerable amount of gluten for individual patients;

- define the role of duodenal biopsy, serology and point of care testing at diagnosis and follow-up;

- find a robust and valid blood marker for diagnosis and monitoring of the disease;

- understand the pathogenesis of RCDI and II.

\section{Author affiliations}

'Department of Medical Epidemiology and Biostatistics, Karolinska Institutet, Stockholm, Sweden

${ }^{2}$ Department of Paediatrics, Örebro University Hospital, Örebro, Sweden

${ }^{3}$ Department of Medicine, Dr C. Bonorino Udaondo Gastroenterology Hospital, Del Salvador University, Buenos Aires, Argentina

${ }^{4}$ Coeliac Centre/1st Department of Internal Medicine, University of Pavia, Fondazione IRCCS Policlinico San Matteo, Pavia, Italy

${ }^{5}$ University of Nottingham, Department of Epidemiology and Public Health, Nottingham City Hospital, Nottingham, UK

${ }^{6}$ Department of Medicine and Surgery, University of Salerno, Salerno, Italy ${ }^{7}$ Gastroenterology, Division of Nutritional Sciences, King's College London, The Rayne Institute, St Thomas Hospital, London, UK

${ }^{8}$ Coeliac Disease Center at Columbia University, New York, New York, USA

${ }^{9}$ Department of Neurology, Royal Hallamshire Hospital, Sheffield, UK

${ }^{10}$ Registered dietitian and representative of the British Dietetic Association, Bath, Somerset, UK

${ }^{11}$ Blizard Institute, Barts and The London School of Medicine and Dentistry, Queen Mary University of London, London, UK

${ }^{12}$ School of Medicine, University of Tampere, Tampere, Finland

${ }^{13}$ Department of Gastroenterology and Alimentary Tract Surgery, Tampere University

Hospital, Tampere, Finland

${ }^{14}$ Department of Medicine, Seinäjoki Central Hospital, Finland

${ }^{15}$ Division of Gastroenterology, Beth Israel Deaconess Medical Center, Harvard

Medical School, Boston, Massachusetts, USA

${ }^{16}$ Department of Dermatology, Imperial College NHS Healthcare Trust, St Mary's

Hospital, London, UK

${ }^{17}$ Department of Gastroenterology, Centre for Immune Regulation, Oslo University

Hospital Rikshospitalet, Oslo, Norway

${ }^{18}$ Coeliac UK, Apollo Centre, London, UK

${ }^{19}$ Patient Representative \& Regional Chairman for Coeliac UK, Sheffield, UK

${ }^{20}$ Division of Gastroenterology and Hepatology, Department of Immunology Mayo

Clinic, Rochester, Minnesota, USA

${ }^{21}$ Department of Gastroenterology, University Hospital Llandough, Wales, UK

${ }^{22}$ Anatomical Pathology, University of Newcastle, Faculty of Health and Medicine,

School of Medicine \& Public Health, Callaghan, Australia

${ }^{23}$ Department of Medicine and Surgery, University of Salerno, Salerno, Italy

${ }^{24}$ Gastroenterology and Liver Unit, Royal Hallamshire Hospital \& University of

Sheffield, Sheffield, UK

Acknowledgements We thank all the patients involved in the related focus groups and discussions.

Contributors JFL and DSS initiated the study. JFL coordinated the project and conducted the web surveys on CD. DSS supervised the project and served as the representative of the British Society of Gastroenterology (BSG). All authors contributed to the literature searches, contributed to the writing of the manuscript, and approved the final version of the manuscript.

Funding JFL was supported by the Swedish Research Council (522-2A09-195) and the Swedish Society of Medicine while writing the draft of this paper. JCB was supported by Consejo en Investigacion en Salud GCABA. KK was supported by The Academy of Finland, the Competitive Research Funding of the Tampere University Hospital (9N062), and The Sigrid Juselius Foundation. JAM was supported by DK 57892. DSS has received an educational grant from Biocard and Simtomax to undertake an investigator-led research studies on $C D$ and/or gluten sensitivity, and an educational grant from Dr Schär (a gluten-free food manufacturer) to undertake an investigator-led research study on gluten sensitivity.

Competing interests DAvH, TRC: received grant support from Coeliac UK. PHRG: scientific advisory board of Alvine Pharmaceuticals and ImmusanT. DAL: Ironwood Pharmaceuticals, Alvine Therapeutics, Alba Pharmaceuticals, Shire Therapeutics, In Nova Diagnostics and CRICO Risk Management Foundation. JAM: consultant for Alba Pharmaceuticals, Alvine Therapeutics, Flamentera, 2GPharma Inc and ImmusanT. KEAL: ImmusanT, Regeneron and Alvine Pharmaceuticals. DSS: received educational grants from Coeliac UK, Biocard, Simtomax and Dr Schär (a gluten-free food manufacturer) to undertake an investigator-led research study on CD and/or gluten sensitivity. 
Ethics approval British Society of Gastroenterology.

Provenance and peer review Not commissioned; externally peer reviewed.

Open Access This is an Open Access article distributed in accordance with the Creative Commons Attribution Non Commercial (CC BY-NC 3.0) license, which permits others to distribute, remix, adapt, build upon this work non-commercially, and license their derivative works on different terms, provided the original work is properly cited and the use is non-commercial. See: http://creativecommons.org/licenses/by-n/3.0/

\section{REFERENCES}

1 Husby S, Koletzko S, Korponay-Szabo IR, et al. European Society for Pediatric Gastroenterology, Hepatology, and Nutrition guidelines for the diagnosis of coeliac disease. J Pediatr Gastroenterol Nutr 2012;54:136-60.

2 Ciclitira P, Dewar DH, McLaughlin SD, et al. The Management of Adults with Coeliac Disease. London: British Society of Gastroenterology, 2010.

3 NICE. Coeliac Disease. Recognition and Assessment of Celiac Disease. London, 2009.

4 Bai JC, Fried M, Corazza GR, et al. World gastroenterology organisation global guidelines on celiac disease. J Clin Gastroenterol 2013;47:121-6.

5 Rubio-Tapia A, Hill ID, Kelly CP, et al. ACG clinical guidelines: diagnosis and management of celiac disease. Am J Gastroenterol 2013;108:656-76; quiz 77.

6 National Institutes of Health Consensus Development Conference Statement on Celiac Disease, June 28-30, 2004. Gastroenterology 2005;128(Suppl 1):S1-9.

7 Ludvigsson JF, Leffler DA, Bai JC, et al. The Oslo definitions for coeliac disease and related terms. Gut 2013;62:43-52.

8 Fasano A, Catassi C. Current approaches to diagnosis and treatment of celiac disease: an evolving spectrum. Gastroenterology 2001;120:636-51.

9 Farrell RJ, Kelly CP. Celiac sprue. N Engl J Med 2002;346:180-8.

10 Green PH, Cellier C. Celiac disease. N Engl J Med 2007;357:1731-43.

11 Green PH, Jabri B. Coeliac disease. Lancet 2003:362:383-91.

12 Di Sabatino A, Corazza GR. Coeliac disease. Lancet 2009:373:1480-93.

13 Schuppan D, Junker Y, Barisani D. Celiac disease: from pathogenesis to novel therapies. Gastroenterology 2009;137:1912-33.

14 van Heel DA, West J. Recent advances in coeliac disease. Gut 2006;55:1037-46.

15 Leffler D. Celiac disease diagnosis and management: a 46-year-old woman with anemia. JAMA 2011;306:1582-92.

16 Walker MM, Murray JA. An update in the diagnosis of coeliac disease. Histopathology 2011;59:166-79.

17 Haines ML, Anderson RP, Gibson PR. Systematic review: the evidence base for long-term management of coeliac disease. Aliment Pharmacol Ther 2008:28:1042-66.

18 Oxford Centre for Evidence-based Medicine - Levels of Evidence. Oxford: Centre for Evidence-based Medicine, Oxford University, 2009

19 Dicke WK, Weijers HA, Van De Kamer JH. Coeliac disease. II. The presence in wheat of a factor having a deleterious effect in cases of coeliac disease. Acta Paediatr 1953:42:34-42.

20 Taylor KB, Truelove SC, Thomson DL, et al. An immunological study of coeliac disease and idiopathic steatorrhoea. Serological reactions to gluten and milk proteins. Br Med J 1961;2:1727-31.

21 Cooke WT, Fone DJ, Cox EV, et al. Adult coeliac disease. Gut 1963:4:279-91.

22 Dube C, Rostom A, Sy R, et al. The prevalence of celiac disease in average-risk and at-risk Western European populations: a systematic review. Gastroenterology 2005;128:S57-67.

23 Corazza GR, Andreani ML, Biagi F, et al. The smaller size of the 'coeliac iceberg' in adults. Scand I Gastroenterol 1997:32:917-19.

24 Maki M, Mustalahti K, Kokkonen J, et al. Prevalence of celiac disease among children in Finland. N Engl J Med 2003:348:2517-24.

25 Mustalahti K, Catassi C, Reunanen A, et al. The prevalence of celiac disease in Europe: results of a centralized, international mass screening project. Ann Med 2010;42:587-95

26 Bingley PJ, Williams AJ, Norcross AJ, et al. Undiagnosed coeliac disease at age seven: population based prospective birth cohort study. BMJ 2004;328:322-3.

27 West J, Logan RF, Hill PG, et al. Seroprevalence, correlates, and characteristics of undetected coeliac disease in England. Gut 2003;52:960-5.

28 Rubio-Tapia A, Ludvigsson JF, Brantner TL, et al. The prevalence of celiac disease in the United States. Am J Gastroenterol 2012;107:1538-44; quiz 37, 45.

29 Murray JA, Van Dyke C, Plevak MF, et al. Trends in the identification and clinical features of celiac disease in a North American community, 1950-2001. Clin Gastroenterol Hepatol 2003;1:19-27.

30 Fasano A, Berti I, Gerarduzzi T, et al. Prevalence of celiac disease in at-risk and not-at-risk groups in the United States: a large multicenter study. Arch Intern Med 2003:163:286-92.

31 Rampertab SD, Pooran N, Brar P, et al. Trends in the presentation of celiac disease. Am J Med 2006;119:355 e9-14.

32 Bergamaschi G, Markopoulos K, Albertini R, et al. Anemia of chronic disease and defective erythropoietin production in patients with celiac disease. Haematologica 2008:93:1785-91.
33 Sanders DS, Carter MJ, Hurlstone DP, et al. Association of adult coeliac disease with irritable bowel syndrome: a case-control study in patients fulfilling ROME II criteria referred to secondary care. Lancet 2001;358:1504-8.

34 Hadjivassiliou M, Gibson A, Davies-Jones GA, et al. Does cryptic gluten sensitivity play a part in neurological illness? [see comments]. Lancet 1996;347:369-71.

35 Ludvigsson JF, Olsson T, Ekbom A, et al. A population-based study of coeliac disease, neurodegenerative and neuroinflammatory diseases. Aliment Pharmacol Ther 2007;25:1317-27.

36 Hadjivassiliou M, Grunewald R, Sharrack B, et al. Gluten ataxia in perspective: epidemiology, genetic susceptibility and clinical characteristics. Brain 2003;126:685-91.

37 Ludvigsson JF, Reutfors J, Osby U, et al. Coeliac disease and risk of mood disorders - a general population-based cohort study. J Affect Disord 2007:99:117-26.

38 Groll A, Candy DC, Preece MA, et al. Short stature as the primary manifestation of coeliac disease. Lancet 1980;2:1097-9.

39 Olmos M, Antelo M, Vazquez $\mathrm{H}$, et al. Systematic review and meta-analysis of observational studies on the prevalence of fractures in coeliac disease. Dig Liver Dis 2008;40:46-53.

40 Ludvigsson JF, Elfstrom P, Broome U, et al.Celiac disease and risk of liver disease: a general population-based study. Clin Gastroenterol Hepatol 2007;5:63-69 e1.

41 Ludvigsson JF, Montgomery SM, Ekbom A. Celiac disease and risk of adverse fetal outcome: a population-based cohort study. Gastroenterology 2005;129: 454-63.

42 West J, Logan RF, Smith CJ, et al. Malignancy and mortality in people with coeliac disease: population based cohort study. BMJ 2004:329:716-19.

43 Meeuwisse GW. Round table discussion. Diagnostic criteria in coeliac disease. Acta Paediatr 1970:59:461-63.

44 McNeish AS, Harms HK, Rey J, et al. The diagnosis of coeliac disease. A commentary on the current practices of members of the European Society for Paediatric Gastroenterology and Nutrition (ESPGAN). Arch Dis Child 1979;54:783-6.

45 Revised Criteria for Diagnosis of Coeliac Disease. Report of Working Group of European Society of Paediatric Gastroenterology and Nutrition. Arch Dis Child 1990:65:909-11.

46 Sollid LM, Lie BA. Celiac disease genetics: current concepts and practical applications. Clin Gastroenterol Hepatol 2005;3:843-51.

47 Welander A, Tjernberg AR, Montgomery SM, et al. Infectious disease and risk of later celiac disease in childhood. Pediatrics 2010;125:e530-6.

48 Greco L, Auricchio S, Mayer M, et al. Case control study on nutritional risk factors in celiac disease. J Pediatr Gastroenterol Nutr 1988;7:395-9.

49 Ivarsson A, Persson LA, Nystrom L, et al. Epidemic of coeliac disease in Swedish children. Acta Paediatr 2000;89:165-71.

50 Stene LC, Honeyman MC, Hoffenberg EJ, et al. Rotavirus infection frequency and risk of celiac disease autoimmunity in early childhood: a longitudinal study. $\mathrm{Am} J$ Gastroenterol 2006;101:2333-40.

51 Riddle MS, Murray JA, Porter CK. The incidence and risk of celiac disease in a healthy US adult population. Am I Gastroenterol 2012;107:1248-55.

52 Jabri B, Sollid LM. Tissue-mediated control of immunopathology in coeliac disease. Nat Rev Immunol 2009;9:858-70.

53 Rubio-Tapia A, Van Dyke CT, Lahr BD, et al. Predictors of family risk for celiac disease: a population-based study. Clin Gastroenterol Hepatol 2008;6:983-7.

54 Greco L, Romino R, Coto I, et al. The first large population based twin study of coeliac disease. Gut 2002;50:624-8.

55 Monsuur AJ, Wijmenga C. Understanding the molecular basis of celiac disease: what genetic studies reveal. Ann Med 2006;38:578-91.

56 Spurkland A, Sollid LM, Polanco I, et al. HLA-DR and -DQ genotypes of celiac disease patients serologically typed to be non-DR3 or non-DR5/7. Hum Immunol 1992;35:188-92.

57 Trynka G, Hunt KA, Bockett NA, et al. Dense genotyping identifies and localizes multiple common and rare variant association signals in celiac disease. Nat Genet 2011:43:1193-201.

58 Garner CP, Murray JA, Ding YC, et al. Replication of celiac disease UK genome-wide association study results in a US population. Hum Mol Genet 2009;18:4219-25.

59 Beitnes AC, Raki M, Lundin KE, et al. Density of CD163+ CD11C+ dendritic cells increases and CD103+ dendritic cells decreases in the coeliac lesion. Scand J Immunol 2011;74:186-94.

60 Raki M, Tollefsen S, Molberg O, et al. A unique dendritic cell subset accumulates in the celiac lesion and efficiently activates gluten-reactive T cells. Gastroenterology 2006:131:428-38.

61 Lundin KE, Scott H, Hansen T, et al. Gliadin-specific, HLA-DQ(alpha 1*0501, beta $\left.1{ }^{*} 0201\right)$ restricted $T$ cells isolated from the small intestinal mucosa of celiac disease patients. J Exp Med 1993;178:187-96.

62 Lundin $\mathrm{KE}$, Scott $\mathrm{H}$, Fausa $\mathrm{O}$, et al. T cells from the small intestinal mucosa of a DR4, DQ7/DR4, DQ8 celiac disease patient preferentially recognize gliadin when presented by DQ8. Hum Immunol 1994;41:285-91. 
63 van de Wal Y, Kooy YM, van Veelen PA, et al. Small intestinal T cells of celiac disease patients recognize a natural pepsin fragment of gliadin. Proc Natl Acad Sci U S A 1998:95:10050-4.

64 Ellis HJ, Pollock EL, Engel W, et al. Investigation of the putative immunodominant T cell epitopes in coeliac disease. Gut 2003:52:212-7.

65 Camarca A, Anderson RP, Mamone G, et al. Intestinal T cell responses to gluten peptides are largely heterogeneous: implications for a peptide-based therapy in celiac disease. J Immunol 2009;182:4158-66.

66 Molberg 0, McAdam SN, Korner R, et al. Tissue transglutaminase selectively modifies gliadin peptides that are recognized by gut-derived $T$ cells in celiac disease [see comments] [published erratum appears in Nat Med 1998 Aug;4 (8):974]. Nat Med 1998;4:713-7.

67 Tollefsen S, Arentz-Hansen H, Fleckenstein B, et al. HLA-DQ2 and -DQ8 signatures of gluten T cell epitopes in celiac disease. J Clin Invest 2006;116: 2226-36.

68 Dieterich $\mathrm{W}$, Ehnis $\mathrm{T}$, Bauer $\mathrm{M}$, et al. Identification of tissue transglutaminase as the autoantigen of celiac disease [see comments]. Nat Med 1997;3: 797-801.

69 Sulkanen S, Halttunen T, Laurila K, et al. Tissue transglutaminase autoantibody enzyme-linked immunosorbent assay in detecting celiac disease [see comments] Gastroenterology 1998;115:1322-8.

70 Di Niro R, Mesin L, Zheng NY, et al. High abundance of plasma cells secreting transglutaminase 2-specific IgA autoantibodies with limited somatic hypermutation in celiac disease intestinal lesions. Nat Med 2012;18:441-5.

71 Rashtak S, Ettore MW, Homburger HA, et al. Comparative usefulness of deamidated gliadin antibodies in the diagnosis of celiac disease. Clin Gastroenterol Hepatol 2008;6:426-32; quiz 370.

72 Tuire I, Marja-Leena L, Teea S, et al. Persistent duodenal intraepithelial lymphocytosis despite a long-term strict gluten-free diet in celiac disease. Am J Gastroenterol 2012;107:1563-9.

73 Rostami K, Mulder CJ, van Overbeek FM, et al. Should relatives of coeliacs with mild clinical complaints undergo a small-bowel biopsy despite negative serology? Eur J Gastroenterol Hepatol 2000;12:51-5.

74 Hammer ST, Greenson JK. The clinical significance of duodenal lymphocytosis with normal villus architecture. Arch Pathol Lab Med 2013;137:1216-19.

75 Dahlbom I, Olsson M, Forooz NK, et al. Immunoglobulin G (IgG) anti-tissue transglutaminase antibodies used as markers for IgA-deficient celiac disease patients. Clin Diagn Lab Immunol 2005;12:254-8.

76 Rashtak S, Ettore MW, Homburger HA, et al. Combination testing for antibodies in the diagnosis of coeliac disease: comparison of multiplex immunoassay and ELISA methods. Aliment Pharmacol Ther 2008:28:805-13.

77 Hill PG, Holmes GK. Coeliac disease: a biopsy is not always necessary for diagnosis. Aliment Pharmacol Ther 2008;27:572-7.

78 Egner W, Shrimpton A, Sargur R, et al. ESPGHAN guidance on coeliac disease 2012: multiples of ULN for decision making do not harmonise assay performance across centres. J Pediatr Gastroenterol Nutr 2012;55:733-5.

79 Lewis NR, Scott BB. Meta-analysis: deamidated gliadin peptide antibody and tissue transglutaminase antibody compared as screening tests for coeliac disease. Aliment Pharmacol Ther 2010;31:73-81.

80 Raivio T, Kaukinen K, Nemes E, et al. Self transglutaminase-based rapid coeliac disease antibody detection by a lateral flow method. Aliment Pharmacol Ther 2006;24:147-54.

81 Korponay-Szabo IR, Szabados K, Pusztai J, et al. Population screening for coeliac disease in primary care by district nurses using a rapid antibody test: diagnostic accuracy and feasibility study. BMJ 2007;335:1244-7.

82 Collin $\mathrm{P}$, Kaukinen $\mathrm{K}$, Vogelsang $\mathrm{H}$, et al. Antiendomysial and antihuman recombinant tissue transglutaminase antibodies in the diagnosis of coeliac disease: a biopsy-proven European multicentre study. Eur J Gastroenterol Hepatol 2005; 17:85-91.

83 Hopper AD, Cross SS, Hurlstone DP, et al. Pre-endoscopy serological testing for coeliac disease: evaluation of a clinical decision tool. BMJ 2007;334:729.

84 Dickey W, Hughes DF, McMillan SA. Reliance on serum endomysial antibody testing underestimates the true prevalence of coeliac disease by one fifth. Scand J Gastroenterol 2000;35:181-3.

85 Murray JA, Herlein J, Mitros F, et al. Serologic testing for celiac disease in the United States: results of a multilaboratory comparison study. Clin Diagn Lab Immunol 2000;7:584-7.

86 Quine MA, Bell GD, McCloy RF, et al. Prospective audit of upper gastrointestinal endoscopy in two regions of England: safety, staffing, and sedation methods. Gut 1995:36:462-7.

87 Lebwohl B, Tennyson CA, Holub JL, et al. Sex and racial disparities in duodenal biopsy to evaluate for celiac disease. Gastrointest Endosc 2012;76:779-85.

88 Nachman F, Vazquez H, Gonzalez A, et al. Gastroesophageal reflux symptoms in patients with celiac disease and the effects of a gluten-free diet. Clin Gastroenterol Hepatol 2011;9:214-9.

89 Margaritte-Jeannin $\mathrm{P}$, Babron MC, Bourgey M, et al. HLA-DQ relative risks for coeliac disease in European populations: a study of the European Genetics Cluster on Coeliac Disease. Tissue Antigens 2004;63:562-7.
90 Karell K, Louka AS, Moodie SJ, et al. HLA types in celiac disease patients not carrying the DQA1*05-DQB1 02 (DQ2) heterodimer: results from the European Genetics Cluster on Celiac Disease. Hum Immunol 2003;64:469-77.

91 Abadie V, Sollid LM, Barreiro LB, et al. Integration of genetic and immunological insights into a model of celiac disease pathogenesis. Annu Rev Immunol 2011;29:493-525

92 Hadithi M, von Blomberg BM, Crusius JB, et al. Accuracy of serologic tests and HLA-DQ typing for diagnosing celiac disease. Ann Intern Med 2007;147: 294-302.

93 Polvi A, Arranz E, Fernandez-Arquero M, et al. HLA-DQ2-negative celiac disease in Finland and Spain. Hum Immunol 1998;59:169-75.

94 Rashtak S, Murray JA. Tailored testing for celiac disease. Ann Intern Med 2007;147:339-41.

95 Dickey W, Hughes D. Disappointing sensitivity of endoscopic markers for villous atrophy in a high-risk population: implications for celiac disease diagnosis during routine endoscopy. Am J Gastroenterol 2001;96:2126-8.

96 Olds G, McLoughlin R, O'Morian C, et al. Celiac disease for the endoscopist. Gastrointest Endosc 2002;56:407-15.

97 Oxentenko AS, Grisolano SW, Murray JA, et al. The insensitivity of endoscopic markers in celiac disease. Am J Gastroenterol 2002;97:933-8.

98 Cammarota G, Fedeli P, Gasbarrini A. Emerging technologies in upper gastrointestinal endoscopy and celiac disease. Nat Clin Pract Gastroenterol Hepatol 2009:6:47-56.

99 Serra S, Jani PA. An approach to duodenal biopsies. J Clin Pathol 2006:59:1133-50.

100 Lebwohl B, Kapel RC, Neugut Al, et al. Adherence to biopsy guidelines increases celiac disease diagnosis. Gastrointest Endosc 2011;74:103-9.

101 Horoldt BS, McAlindon ME, Stephenson TJ, et al. Making the diagnosis of coeliac disease: is there a role for push enteroscopy? Eur J Gastroenterol Hepatol 2004;16:1143-6.

102 Chang MS, Rubin M, Lewis SK, et al. Diagnosing celiac disease by video capsule endoscopy (VCE) when esophogastroduodenoscopy (EGD) and biopsy is unable to provide a diagnosis: a case series. BMC Gastroenterol 2012;12:90.

103 Elfstrom P, Granath F, Ekstrom Smedby K, et al. Risk of lymphoproliferative malignancy in relation to small intestinal histopathology among patients with celiac disease. J Nat/ Cancer Inst 2011;103:436-44.

104 Tennyson CA, Ciaccio EJ, Lewis SK. Video capsule endoscopy in celiac disease. Gastrointest Endosc Clin N Am 2012;22:747-58.

105 Atlas DS, Rubio-Tapia A, Van Dyke CT, et al. Capsule endoscopy in nonresponsive celiac disease. Gastrointest Endosc 2011;74:1315-22.

106 Kurppa K, Collin P, Viljamaa M, et al. Diagnosing mild enteropathy celiac disease: a randomized, controlled clinical study. Gastroenterology 2009;136:816-23.

107 Marsh MN. Gluten, major histocompatibility complex, and the small intestine. A molecular and immunobiologic approach to the spectrum of gluten sensitivity ('celiac sprue'). Gastroenterology 1992;102:330-54.

108 Oberhuber G, Granditsch G, Vogelsang H. The histopathology of coeliac disease: time for a standardized report scheme for pathologists. Eur J Gastroenterol Hepatol 1999;11:1185-94.

109 Corazza GR, Villanacci V. Coeliac disease. J Clin Pathol 2005;58:573-4.

110 Rostami K, Villanacci V. Microscopic enteritis: novel prospect in coeliac disease clinical and immuno-histogenesis. Evolution in diagnostic and treatment strategies. Dig Liver Dis 2009:41:245-52.

111 Walker MM, Murray JA, Ronkainen J, et al. Detection of celiac disease and lymphocytic enteropathy by parallel serology and histopathology in a population-based study. Gastroenterology 2010;139:112-19.

112 Villanacci V, Ceppa P, Tavani E, et al. Coeliac disease: the histology report. Dig Liver Dis 2011;43(Suppl 4):S385-95.

113 Arguelles-Grande C, Tennyson CA, Lewis SK, et al. Variability in small bowel histopathology reporting between different pathology practice settings: impact on the diagnosis of coeliac disease. J Clin Pathol 2012;65:242-7.

114 Ensari A. Gluten-sensitive enteropathy (celiac disease): controversies in diagnosis and classification. Arch Pathol Lab Med 2010;134:826-36.

115 Biagi F, Luinetti 0, Campanella J, et al. Intraepithelial lymphocytes in the villous tip: do they indicate potential coeliac disease? J Clin Pathol 2004;57:835-9.

116 Jarvinen $\mathrm{TT}$, Collin $\mathrm{P}$, Rasmussen $\mathrm{M}$, et al. Villous tip intraepithelial lymphocytes as markers of early-stage coeliac disease. Scand J Gastroenterol 2004;39: 428-33.

117 Corazza GR, Villanacci V, Zambelli C, et al. Comparison of the interobserver reproducibility with different histologic criteria used in celiac disease. Clin Gastroenterol Hepatol 2007:5:838-43.

118 Brown I, Mino-Kenudson M, Deshpande V, et al. Intraepithelial lymphocytosis in architecturally preserved proximal small intestinal mucosa: an increasing diagnostic problem with a wide differential diagnosis. Arch Pathol Lab Med 2006:130:1020-5.

119 Daum S, Cellier C, Mulder CJ. Refractory coeliac disease. Best Pract Res Clin Gastroenterol 2005;19:413-24.

120 Rubio-Tapia A, Murray JA. Classification and management of refractory coeliac disease. Gut 2010:59:547-57. 
121 Aziz I, Evans KE, Hopper AD, et al. A prospective study into the aetiology of lymphocytic duodenosis. Aliment Pharmacol Ther 2010;32:1392-7.

122 Rubio-Tapia A, Herman ML, Ludvigsson JF, et al. Severe spruelike enteropathy associated with olmesartan. Mayo Clin Proc 2012;87:732-8.

123 Pallav K, Leffler DA, Tariq S, et al. Noncoeliac enteropathy: the differential diagnosis of villous atrophy in contemporary clinical practice. Aliment Pharmacol Ther 2012;35:380-90.

124 Koskinen O, Collin P, Lindfors K, et al. Usefulness of small-bowel mucosal transglutaminase-2 specific autoantibody deposits in the diagnosis and follow-up of celiac disease. J Clin Gastroenterol 2010:44:483-8.

125 Carroccio A, lacono G, D'Amico D, et al. Production of anti-endomysial antibodies in cultured duodenal mucosa: usefulness in coeliac disease diagnosis. Scand J Gastroenterol 2002;37:32-8.

126 Carroccio A, Di Prima L, Pirrone G, et al. Anti-transglutaminase antibody assay of the culture medium of intestinal biopsy specimens can improve the accuracy of celiac disease diagnosis. Clin Chem 2006:52:1175-80.

127 Banerjee R, Reddy DN. High-resolution narrow-band imaging can identify patchy atrophy in celiac disease: targeted biopsy can increase diagnostic yield. Gastrointest Endosc 2009:69:984-5.

128 Siegel LM, Stevens PD, Lightdale CJ, et al. Combined magnification endoscopy with chromoendoscopy in the evaluation of patients with suspected malabsorption. Gastrointest Endosc 1997;46:226-30.

129 Leonard J, Haffenden G, Tucker W, et al. Gluten challenge in dermatitis herpetiformis. N Engl J Med 1983;308:816-19.

130 Seah PP, Fry L. Immunoglobulins in the skin in dermatitis herpetiformis and their relevance in diagnosis. Br J Dermatol 1975;92:157-66.

131 Fry L, Leonard JN, Swain F, et al. Long term follow-up of dermatitis herpetiformis with and without dietary gluten withdrawal. Br J Dermatol 1982; 107:631-40.

132 Fry L, Seah PP, Harper PG, et al. The small intestine in dermatitis herpetiformis. J Clin Pathol 1974;27:817-24.

133 Lewis HM, Renaula TL, Garioch JJ, et al. Protective effect of gluten-free diet against development of lymphoma in dermatitis herpetiformis. $\mathrm{Br} J$ Dermatol 1996:135:363-7.

134 Hall NJ, Rubin G, Charnock A. Systematic review: adherence to a gluten-free diet in adult patients with coeliac disease. Aliment Pharmacol Ther 2009:30:315-30.

135 Mayer M, Greco L, Troncone R, et al. Compliance of adolescents with coeliac disease with a gluten free diet. Gut 1991:32:881-5.

136 Bardella MT, Molteni N, Prampolini L, et al. Need for follow up in coeliac disease. Arch Dis Child 1994;70:211-3.

137 Ljungman G, Myrdal U. Compliance in teenagers with coeliac disease-a Swedish follow-up study. Acta Paediatr 1993;82:235-8.

138 Kolsteren MM, Koopman HM, Schalekamp G, et al. Health-related quality of life in children with celiac disease. J Pediatr 2001;138:593-5.

139 Pietzak MM. Follow-up of patients with celiac disease: achieving compliance with treatment. Gastroenterology 2005;128:S135-41.

140 Leffler DA, Edwards-George J, Dennis $M$, et al. Factors that influence adherence to a gluten-free diet in adults with celiac disease. Dig Dis Sci 2008;53:1573-81.

141 Dickey W, Ward M, Whittle CR, et al. Homocysteine and related B-vitamin status in coeliac disease: effects of gluten exclusion and histological recovery. Scand $\mathrm{J}$ Gastroentero/ 2008;43:682-8.

142 Saibeni S, Lecchi A, Meucci G, et al. Prevalence of hyperhomocysteinemia in adult gluten-sensitive enteropathy at diagnosis: role of B12, folate, and genetics. Clin Gastroenterol Hepatol 2005:3:574-80.

143 Ciacci C, Spagnuolo G, Tortora R, et al. Urinary stone disease in adults with celiac disease: prevalence, incidence and urinary determinants. J Uro/ 2008;180:974-9.

144 Stenson WF, Newberry R, Lorenz R, et al. Increased prevalence of celiac disease and need for routine screening among patients with osteoporosis. Arch Intern Med 2005;165:393-9.

145 Elfstrom P, Montgomery SM, Kampe 0, et al. Risk of thyroid disease in individuals with celiac disease. J Clin Endocrinol Metab 2008:93:3915-21.

146 Rapoport MJ, Bistritzer T, Vardi O, et al. Increased prevalence of diabetes-related autoantibodies in celiac disease. J Pediatr Gastroenterol Nutr 1996:23:524-7.

147 Ludvigsson JF, Ludvigsson J, Ekbom A, et al. Celiac disease and risk of subsequent Type 1 diabetes: a general population cohort study of children and adolescents. Diabetes Care 2006;29:2483-8.

148 Tursi A, Brandimarte G, Giorgetti GM. Lack of usefulness of anti-transglutaminase antibodies in assessing histologic recovery after gluten-free diet in celiac disease. J Clin Gastroenterol 2003;37:387-91.

149 Vahedi K, Mascart F, Mary JY, et al. Reliability of antitransglutaminase antibodies as predictors of gluten-free diet compliance in adult celiac disease. $\mathrm{Am} J$ Gastroenterol 2003:98:1079-87.

150 Rubio-Tapia A, Rahim MW, See JA, et al. Mucosal recovery and mortality in adults with celiac disease after treatment with a gluten-free diet. Am J Gastroenterol 2010; 105:1412-20

151 Kaukinen $\mathrm{K}$, Peraaho $\mathrm{M}$, Lindfors $\mathrm{K}$, et al. Persistent small bowel mucosal villous atrophy without symptoms in coeliac disease. Aliment Pharmacol Ther 2007:25:1237-45.
152 Dickey W, Hughes DF, McMillan SA. Patients with serum IgA endomysial antibodies and intact duodenal villi: clinical characteristics and management options. Scand J Gastroenterol 2005:40:1240-3.

153 Hopper AD, Hadjivassiliou M, Hurlstone DP, et al. What is the role of serologic testing in celiac disease? A prospective, biopsy-confirmed study with economic analysis. Clin Gastroenterol Hepatol 2008;6:314-20.

154 Dickey W, Hughes DF, McMillan SA. Disappearance of endomysial antibodies in treated celiac disease does not indicate histological recovery [in process citation] Am J Gastroenterol 2000;95:712-4.

155 Lebwohl B, Murray JA, Rubio-Tapia A, et al. Predictors of persistent villous atrophy in coeliac disease: a population-based study. Aliment Pharmacol Ther 2014:39:488-95.

156 Hutchinson JM, West NP, Robins GG, et al. Long-term histological follow-up of people with coeliac disease in a UK teaching hospital. OJM 2010;103:511-17.

157 Selby WS, Painter D, Collins A, et al. Persistent mucosal abnormalities in coeliac disease are not related to the ingestion of trace amounts of gluten. Scand $J$ Gastroenterol 1999;34:909-14.

158 Ciacci C, Cirillo M, Cavallaro R, et al. Long-term follow-up of celiac adults on gluten-free diet: prevalence and correlates of intestinal damage. Digestion 2002;66:178-85.

159 Lanzini A, Lanzarotto F, Villanacci V, et al. Complete recovery of intestinal mucosa occurs very rarely in adult coeliac patients despite adherence to gluten-free diet. Aliment Pharmacol Ther 2009:29:1299-308.

160 Wahab PJ, Meijer JW, Mulder CJ. Histologic follow-up of people with celiac disease on a gluten-free diet: slow and incomplete recovery. Am J Clin Pathol 2002;118:459-63.

161 Sainsbury A, Sanders DS, Ford AC. Prevalence of irritable bowel syndrome-type symptoms in patients with celiac disease: a meta-analysis. Clin Gastroenterol Hepatol 2013;11:359-65.e1.

162 Ciacci C, lavarone A, Mazzacca G, et al. Depressive symptoms in adult coeliac disease. Scand J Gastroenterol 1998;33:247-50.

163 Edwards George JB, Leffler DA, Dennis MD, et al. Psychological correlates of gluten-free diet adherence in adults with celiac disease. J Clin Gastroenterol 2009;43:301-6.

164 Leffler DA, Dennis M, Edwards George JB, et al. A simple validated gluten-free diet adherence survey for adults with celiac disease. Clin Gastroenterol Hepatol 2009; 7:530-6, 36 e1-2.

165 Sainsbury K, Mullan B. Measuring beliefs about gluten free diet adherence in adult coeliac disease using the theory of planned behaviour. Appetite 2011;56:476-83.

166 Chauhan JC, Kumar P, Dutta AK, et al. Assessment of dietary compliance to gluten free diet and psychosocial problems in Indian children with celiac disease. Indian J Pediatr 2010;77:649-54.

167 Ciacci C, D'Agate C, De Rosa A, et al. Self-rated quality of life in celiac disease. Dig Dis Sci 2003;48:2216-20.

168 Hopman EG, Koopman HM, Wit JM, et al. Dietary compliance and health-related quality of life in patients with coeliac disease. Eur J Gastroenterol Hepatol 2009;21:1056-61.

169 Hogberg L, Grodzinsky E, Stenhammar L. Better dietary compliance in patients with coeliac disease diagnosed in early childhood. Scand J Gastroenterol 2003:38:751-4

170 Biagi F, Bianchi PI, Marchese A, et al. A score that verifies adherence to a gluten-free diet: a cross-sectional, multicentre validation in real clinical life. $\mathrm{Br}$ J Nutr 2012;108:1884-8.

171 Charalampopoulos D, Panayiotou J, Chouliaras G, et al. Determinants of adherence to gluten-free diet in Greek children with coeliac disease: a cross-sectional study. Eur J Clin Nutr 2013:67:615-19.

172 Kurppa K, Lauronen 0, Collin P, et al. Factors associated with dietary adherence in celiac disease: a nationwide study. Digestion 2012;86:309-14.

173 van Hees NJ, Van der Does W, Giltay EJ. Coeliac disease, diet adherence and depressive symptoms. J Psychosom Res 2013;74:155-60.

174 Lebwohl B, Granath F, Ekbom A, et al. Mucosal healing and mortality in coeliac disease. Aliment Pharmacol Ther 2013;37:332-9.

175 Lebwohl B, Granath F, Ekbom A, et al. Mucosal healing and risk for lymphoproliferative malignancy in celiac disease: a population-based cohort study. Ann Intern Med 2013:159:169-75.

176 Leffler D, Schuppan D, Pallav K, et al. Kinetics of the histological, serological and symptomatic responses to gluten challenge in adults with coeliac disease. Gut 2013;62:996-1004.

177 Herman ML, Rubio-Tapia A, Lahr BD, et al. Patients with celiac disease are not followed up adequately. Clin Gastroenterol Hepatol 2012;10:893-99 e1.

178 Bebb JR, Lawson A, Knight T, et al. Long-term follow-up of coeliac disease-what do coeliac patients want? Aliment Pharmacol Ther 2006:23:827-31.

179 Corazza GR, Di Sario A, Cecchetti L, et al. Bone mass and metabolism in patients with celiac disease. Gastroenterology 1995:109:122-8.

180 Corazza GR, Di Stefano M, Maurino E, et al. Bones in coeliac disease: diagnosis and treatment. Best Pract Res Clin Gastroenterol 2005;19:453-65.

181 McFarlane XA, Bhalla AK, Reeves DE, et al. Osteoporosis in treated adult coeliac disease. Gut 1995:36:710-14. 
182 Passananti V, Santonicola A, Bucci C, et al. Bone mass in women with celiac disease: role of exercise and gluten-free diet. Dig Liver Dis 2012;44:379-83.

183 Capriles VD, Martini LA, Areas JA. Metabolic osteopathy in celiac disease: importance of a gluten-free diet. Nutr Rev 2009;67:599-606.

184 West J, Logan RF, Card TR, et al. Fracture risk in people with celiac disease: a population-based cohort study. Gastroenterology 2003;125:429-36.

185 Vestergaard P, Mosekilde L. Fracture risk in patients with celiac Disease, Crohn's disease, and ulcerative colitis: a nationwide follow-up study of 16,416 patients in Denmark. Am J Epidemiol 2002;156:1-10.

186 Vasquez H, Mazure R, Gonzalez D, et al. Risk of fractures in celiac disease patients: a cross-sectional, case- control study. Am J Gastroenterol 2000;95:183-9.

187 Moreno ML, Vazquez H, Mazure R, et al. Stratification of bone fracture risk in patients with celiac disease. Clin Gastroenterol Hepatol 2004;2:127-34.

188 Davie MW, Gaywood I, George E, et al. Excess non-spine fractures in women over 50 years with celiac disease: a cross-sectional, questionnaire-based study. Osteoporos Int 2005;16:1150-5.

189 Ludvigsson JF, Michaelsson K, Ekbom A, et al. Coeliac disease and the risk of fractures-a general population-based cohort study. Aliment Pharmacol Ther 2007; 25:273-85.

190 Jafri MR, Nordstrom CW, Murray JA, et al. Long-term fracture risk in patients with celiac disease: a population-based study in Olmsted County, Minnesota. Dig Dis Sci 2007;53:964-71.

191 Corazza GR, Di Sario A, Cecchetti L, et al. Influence of pattern of clinical presentation and of gluten-free diet on bone mass and metabolism in adult coeliac disease. Bone 1996:18:525-30.

192 Bai JC, Gonzalez D, Mautalen C, et al. Long-term effect of gluten restriction on bone mineral density of patients with coeliac disease. Aliment Pharmacol Ther 1997:11:157-64

193 Valdimarsson T, Lofman O, Toss G, et al. Reversal of osteopenia with diet in adult coeliac disease. Gut 1996;38:322-7.

194 Ciacci C, Maurelli L, Klain M, et al. Effects of dietary treatment on bone mineral density in adults with celiac disease: factors predicting response. Am J Gastroenterol 1997:92:992-6.

195 Mautalen C, Gonzalez D, Mazure R, et al. Effect of treatment on bone mass, mineral metabolism, and body composition in untreated celiac disease patients. Am I Gastroenterol 1997:92:313-18.

196 Committee to Review Dietary Reference Intakes for Vitamin D and Calcium, Food and Nutrition Board, Institute of Medicine. Dietary Reference Intakes for Calcium and Vitamin D. Washington DC, 2010.

197 Malabanan AO, Holick MF. Vitamin D and bone health in postmenopausal women. J Womens Health (Larchmt) 2003:12:151-6.

198 Di Sabatino A, Rosado MM, Cazzola P, et al. Splenic hypofunction and the spectrum of autoimmune and malignant complications in celiac disease. Clin Gastroenterol Hepatol 2006;4:179-86.

199 Ludvigsson JF, Olen O, Bell M, et al. Coeliac disease and risk of sepsis. Gut 2008;57:1074-80

200 Thomas HJ, Wotton CJ, Yeates D, et al. Pneumococcal infection in patients with coeliac disease. Eur J Gastroenterol Hepatol 2008;20:624-8.

201 Corazza GR, Frisoni M, Vaira D, et al. Effect of gluten-free diet on splenic hypofunction of adult coeliac disease. Gut 1983;24:228-30.

202 Primary Care Society for Gastroenterology UK. The Management of Adults with Coeliac Disease in Primary Care, 2006.

203 Marild K, Fredlund H, Ludvigsson JF. Increased risk of hospital admission for influenza in patients with celiac disease: a nationwide cohort study in Sweden. Am J Gastroenterol 2010;105:2465-73.

204 McKinley M, Leibowitz S, Bronzo R, et al. Appropriate response to pneumococcal vaccine in celiac sprue. J Clin Gastroenterol 1995;20:113-16.

205 Noh KW, Poland GA, Murray JA. Hepatitis B vaccine nonresponse and celiac disease. Am J Gastroenterol 2003;98:2289-92.

206 Zingone F, Morisco F, Zanetti A, et al. Long-term antibody persistence and immune memory to hepatitis $B$ virus in adult celiac patients vaccinated as adolescents. Vaccine 2011;29:1005-8

207 Myleus A, Ivarsson A, Webb C, et al. Celiac disease revealed in 3\% of Swedish 12-year-olds born during an epidemic. J Pediatr Gastroenterol Nutr 2009;49:170-6.

208 Vilppula A, Kaukinen K, Luostarinen L, et al. Increasing prevalence and high incidence of celiac disease in elderly people: a population-based study. BMC Gastroenterol 2009:9:49.

209 Katz KD, Rashtak S, Lahr BD, et al. Screening for celiac disease in a North American population: sequential serology and gastrointestinal symptoms. Am J Gastroenterol 2011;106:1333-9.

210 Collin $\mathrm{P}$, Huhtala $H$, Virta $L$, et al. Diagnosis of celiac disease in clinical practice: physician's alertness to the condition essential. J Clin Gastroenterol 2007:41:152-6.

211 Murray JA, Watson T, Clearman B, et al. Effect of a gluten-free diet on gastrointestinal symptoms in celiac disease. Am J Clin Nutr 2004;79:669-73.

212 Holmes GK, Prior P, Lane MR, et al. Malignancy in coeliac disease-effect of a gluten free diet. Gut 1989:30:333-8.

213 Sanchez MI, Mohaidle A, Baistrocchi A, et al. Risk of fracture in celiac disease: gender, dietary compliance, or both? World I Gastroenterol 2011;17:3035-42.
214 Johnston SD, Rodgers C, Watson RG. Quality of life in screen-detected and typical coeliac disease and the effect of excluding dietary gluten. Eur I Gastroenterol Hepatol 2004;16:1281-6.

215 Whitaker JK, West J, Holmes GK, et al. Patient perceptions of the burden of coeliac disease and its treatment in the UK. Aliment Pharmacol Ther 2009;29:1131-6.

216 Ukkola A, Maki M, Kurppa K, et al. Patients' experiences and perceptions of living with coeliac disease-implications for optimizing care. J Gastrointestin Liver Dis 2012;21:17-22.

217 Nordyke K, Norstrom F, Lindholm L, et al. Health-related quality-of-life in children with coeliac disease, measured prior to receiving their diagnosis through screening. J Med Screen 2011;18:187-92.

218 Johnston SD, Watson RG, McMillan SA, et al. Coeliac disease detected by screening is not silent—simply unrecognized. QJM 1998;91:853-60.

219 Rubio-Tapia A, Kyle RA, Kaplan EL, et al. Increased prevalence and mortality in undiagnosed celiac disease. Gastroenterology 2009;137:88-93.

220 Ukkola A, Maki M, Kurppa K, et al. Diet improves perception of health and well-being in symptomatic, but not asymptomatic, patients with celiac disease. Clin Gastroenterol Hepatol 2011;9:118-23.

221 Nachman F, Maurino E, Vazquez H, et al. Quality of life in celiac disease patients: prospective analysis on the importance of clinical severity at diagnosis and the impact of treatment. Dig Liver Dis 2009;41:15-25.

222 Mustalahti K, Lohiniemi S, Collin P, et al. Gluten-free diet and quality of life in patients with screen-detected celiac disease. Eff Clin Pract 2002;5:105-13.

223 van Koppen EJ, Schweizer JJ, Csizmadia CG, et al. Long-term health and quality-of-life consequences of mass screening for childhood celiac disease: a 10-year follow-up study. Pediatrics 2009;123:e582-8.

224 Hin $\mathrm{H}$, Bird G, Fisher $\mathrm{P}$, et al. Coeliac disease in primary care: case finding study. BMJ 1999;318:164-7.

225 Marild K, Stephansson O, Grahnquist L, et al. Down syndrome is associated with elevated risk of celiac disease: a nationwide case-control study. J Pediatr 2013;163:237-42.

226 Vestergaard P, Mosekilde L. Fractures in patients with hyperthyroidism and hypothyroidism: a nationwide follow-up study in 16,249 patients. Thyroid 2002;12:411-19.

227 Halfdanarson TR, Litzow MR, Murray JA. Hematological manifestations of celiac disease. Blood 2006;109:412-21.

228 Ford AC, Chey WD, Talley NJ, et al. Yield of diagnostic tests for celiac disease in individuals with symptoms suggestive of irritable bowel syndrome: systematic review and meta-analysis. Arch Intern Med 2009;169:651-8.

229 Green PHR, Stavropoulos SN, Panagi SG, et al. Characteristics of adult celiac disease in the USA: results of a national survey. Am J Gastroenterol 2001;96:126-31.

230 Ciacci C, lavarone A, Siniscalchi M, et al. Psychological dimensions of celiac disease: toward an integrated approach. Dig Dis Sci 2002;47:2082-7.

231 de Rosa A, Troncone A, Vacca M, et al. Characteristics and quality of illness behaviour in celiac disease. Psychosomatics 2004;45:336-42.

232 Hauser W, Gold J, Stein J, et al. Health-related quality of life in adult coeliac disease in Germany: results of a national survey. Eur J Gastroenterol Hepatol 2006;18:747-54.

233 Vilppula A, Kaukinen K, Luostarinen L, et al. Clinical benefit of gluten-free diet in screen-detected older celiac disease patients. BMC Gastroenterol 2011;11:136.

234 Smith DF, Gerdes LU. Meta-analysis on anxiety and depression in adult celiac disease. Acta Psychiatr Scand 2012;125:189-93.

235 Sanders DS, Patel D, Stephenson TJ, et al. A primary care cross-sectional study of undiagnosed adult coeliac disease. Eur J Gastroenterol Hepatol 2003;15:407-13.

236 Platt SG, Kasarda DD. Separation and characterization of — gliadin fractions. Biochim Biophys Acta 1971;243:407-15.

237 Janatuinen EK, Pikkarainen PH, Kemppainen TA, et al. A comparison of diets with and without oats in adults with celiac disease. N Engl J Med 1995;333:1033-7.

238 Janatuinen EK, Kemppainen TA, Pikkarainen PH, et al. Lack of cellular and humoral immunological responses to oats in adults with coeliac disease. Gut 2000;46:327-31.

239 Sadiq Butt M, Tahir-Nadeem M, Khan MK, et al. Oat: unique among the cereals. Eur J Nutr 2008;47:68-79.

240 Comino I, Real A, de Lorenzo L, et al. Diversity in oat potential immunogenicity: basis for the selection of oat varieties with no toxicity in coeliac disease. Gut 2011;60:915-22.

241 Lundin KE, Nilsen EM, Scott HG, et al. Oats induced villous atrophy in coeliac disease. Gut 2003;52:1649-52.

242 Arentz-Hansen $\mathrm{H}$, Fleckenstein B, Molberg $\mathrm{O}$, et al. The molecular basis for oat intolerance in patients with celiac disease. PloS Med 2004;1:e1.

243 Case $S$. The gluten-free diet: how to provide effective education and resources. Gastroenterology 2005;128:S128-34.

244 Wild D, Robins GG, Burley VJ, et al. Evidence of high sugar intake, and low fibre and mineral intake, in the gluten-free diet. Aliment Pharmacol Ther 2010:32:573-81. 
245 Ukkola A, Maki M, Kurppa K, et al. Changes in body mass index on a gluten-free diet in coeliac disease: a nationwide study. Eur J Intern Med 2012;23:384-8.

246 Nelson M, Mendoza N, McGough N. A survey of provision of dietetic services for coeliac disease in the UK. J Hum Nutr Diet 2007;20:403-11.

247 Leffler D, Vanga R, Mukherjee R. Mild enteropathy celiac disease: a wolf in sheep's clothing? Clin Gastroenterol Hepatol 2013;11:259-61.

248 Akobeng AK, Thomas AG. Systematic review: tolerable amount of gluten for people with coeliac disease. Aliment Pharmacol Ther 2008;27:1044-52.

249 Hischenhuber C, Crevel R, Jarry B, et al. Review article: safe amounts of gluten for patients with wheat allergy or coeliac disease. Aliment Pharmacol Ther 2006;23:559-75.

250 Ventura A, Magazzu G, Greco L. Duration of exposure to gluten and risk for autoimmune disorders in patients with celiac disease. SIGEP Study Group for Autoimmune Disorders in Celiac Disease. Gastroenterology 1999;117:297-303.

251 Corrao G, Corazza GR, Bagnardi V, et al. Mortality in patients with coeliac disease and their relatives: a cohort study. Lancet 2001;358:356-61.

252 Khashan AS, Henriksen TB, Mortensen PB, et al. The impact of maternal celiac disease on birthweight and preterm birth: a Danish population-based cohort study. Hum Reprod 2010;25:528-34.

253 Silano M, Volta U, Vincenzi AD, et al. Effect of a gluten-free diet on the risk of enteropathy-associated T-cell lymphoma in celiac disease. Dig Dis Sci 2008;53:972-6.

254 Green PH, Fleischauer AT, Bhagat G, et al. Risk of malignancy in patients with celiac disease. Am J Med 2003;115:191-5.

255 Olen $\mathrm{O}$, Askling J, Ludvigsson JF, et al. Coeliac disease characteristics, compliance to a gluten free diet and risk of lymphoma by subtype. Dig Liver Dis 2011:43:862-8.

256 Karajeh MA, Hurlstone DP, Patel TM, et al. Chefs' knowledge of coeliac disease (compared to the public): a questionnaire survey from the United Kingdom. Clin Nutr 2005;24:206-10.

257 Singh J, Whelan K. Limited availability and higher cost of gluten-free foods. J Hum Nutr Diet 2011:24:479-86.

258 Lee AR, Ng DL, Zivin J, et al. Economic burden of a gluten-free diet. J Hum Nutr Diet 2007:20:423-30.

259 Drossman DA, Brandt L, Sears C, et al. A preliminary study of patients' concerns related to Gl endoscopy. Am J Gastroenterol 1996:91:287-91.

260 Ford S, Howard R, Oyebode J. Psychosocial aspects of coeliac disease: a cross-sectional survey of a UK population. Br J Health Psychol 2012:17:743-57.

261 Lee AR, Ng DL, Diamond B, et al. Living with coeliac disease: survey results from the USA. J Hum Nutr Diet 2012;25:233-8.

262 Bystrom IM, Hollen E, Falth-Magnusson K, et al. Health-related quality of life in children and adolescents with celiac disease: from the perspectives of children and parents. Gastroenterol Res Pract 2012;2012:986475.

263 Nachman F, del Campo MP, Gonzalez A, et al. Long-term deterioration of quality of life in adult patients with celiac disease is associated with treatment noncompliance. Dig Liver Dis 2010;42:685-91.

264 Long KH, Rubio-Tapia A, Wagie AE, et al. The economics of coeliac disease: a population-based study. Aliment Pharmacol Ther 2010;32:261-9.

265 Leffler DA, Dennis M, Hyett B, et al. Etiologies and predictors of diagnosis in nonresponsive celiac disease. Clin Gastroenterol Hepatol 2007;5:445-50.

266 Abdulkarim AS, Burgart LJ, See J, et al. Etiology of nonresponsive celiac disease: results of a systematic approach. Am I Gastroenterol 2002;97:2016-21.

267 Biagi F, Corazza GR. Defining gluten refractory enteropathy. Eur I Gastroenterol Hepatol 2001:13:561-5.

268 Fine KD, Meyer RL, Lee EL. The prevalence and causes of chronic diarrhea in patients with celiac sprue treated with a gluten-free diet. Gastroenterology 1997:112:1830-8

269 Dewar DH, Donnelly SC, McLaughlin SD, et al. Celiac disease: management of persistent symptoms in patients on a gluten-free diet. World I Gastroenterol 2012;18:1348-56.

270 Dickey W. Colon neoplasia co-existing with coeliac disease in older patients: coincidental, probably; important, certainly. Scand I Gastroenterol 2002:37:1054-6.

271 Leeds JS, Hopper AD, Hurlstone DP, et al. Is exocrine pancreatic insufficiency in adult coeliac disease a cause of persisting symptoms? Aliment Pharmacol Ther 2007;25:265-71.

272 Olesen M, Eriksson S, Bohr J, et al. Microscopic colitis: a common diarrhoeal disease. An epidemiological study in Orebro, Sweden, 1993-1998. Gut 2004:53:346-50.

273 Cellier C, Delabesse E, Helmer C, et al. Refractory sprue, coeliac disease, and enteropathy-associated T-cell lymphoma. French Coeliac Disease Study Group. Lancet 2000;356:203-8.

274 Rubio-Tapia A, Kelly DG, Lahr BD, et al. Clinical staging and survival in refractory celiac disease: a single center experience. Gastroenterology 2009;136:99-107; quiz 352-3.

275 Malamut G, Afchain P, Verkarre V, et al. Presentation and long-term follow-up of refractory celiac disease: comparison of type I with type II. Gastroenterology 2009;136:81-90.

276 Biagi F, Lorenzini P, Corazza GR. Literature review on the clinical relationship between ulcerative jejunoileitis, coeliac disease, and enteropathy-associated T-cell. Scand J Gastroenterol 2000:35:785-90.
277 Goerres MS, Meijer JW, Wahab PJ, et al. Azathioprine and prednisone combination therapy in refractory coeliac disease. Aliment Pharmacol Ther 2003;18:487-94.

278 Maurino E, Niveloni S, Chernavsky A, et al. Azathioprine in refractory sprue: results from a prospective, open-label study. Am J Gastroenterol 2002;97:2595-602.

279 Gale J, Simmonds PD, Mead GM, et al. Enteropathy-type intestinal T-cell Iymphoma: clinical features and treatment of 31 patients in a single center. J Clin Oncol 2000;18:795-803.

280 Domizio P, Owen RA, Shepherd NA, et al. Primary lymphoma of the small intestine. A clinicopathological study of 119 cases. Am I Surg Pathol 1993;17:429-42.

281 Deleeuw RJ, Zettl A, Klinker E, et al. Whole-genome analysis and HLA genotyping of enteropathy-type T-cell lymphoma reveals 2 distinct lymphoma subtypes. Gastroenterology 2007:132:1902-11

282 Kane EV, Newton R, Roman E. Non-Hodgkin lymphoma and gluten-sensitive enteropathy: estimate of risk using meta-analyses. Cancer Causes Control 2011;22:1435-44

283 Zettl A, deLeeuw R, Haralambieva E, et al. Enteropathy-type T-cell lymphoma. Am J Clin Pathol 2007;127:701-6.

284 Smedby KE, Akerman M, Hildebrand $\mathrm{H}$, et al. Malignant lymphomas in coeliac disease: evidence of increased risks for lymphoma types other than enteropathy-type T cell lymphoma. Gut 2005;54:54-9.

285 Leslie LA, Lebwohl B, Neugut Al, et al. Incidence of lymphoproliferative disorders in patients with celiac disease. Am J Hematol 2012;87:754-9.

286 Olen 0, Askling J, Ludvigsson JF, et al. Coeliac disease characteristics, compliance to a gluten free diet and risk of lymphoma by subtype. Dig Liver Dis 2011:43:862-8.

287 Moertel CG, Hargraves MM. Coexistence of adenocarcinoma of the jejunum and nontropical sprue. JAMA 1961;176:612-4.

288 Card TR, West J, Holmes GK. Risk of malignancy in diagnosed coeliac disease: a 24-year prospective, population-based, cohort study. Aliment Pharmacol Ther 2004:20:769-75.

289 Elfstrom P, Granath F, Ye W, et al. Low risk of gastrointestinal cancer among patients with celiac disease, inflammation, or latent celiac disease. Clin Gastroenterol Hepatol 2012;10:30-6.

290 McSorley HJ, Gaze S, Daveson J, et al. Suppression of inflammatory immune responses in celiac disease by experimental hookworm infection. PloS ONE 2011;6:e24092.

291 Daveson AJ, Jones DM, Gaze S, et al. Effect of hookworm infection on wheat challenge in celiac disease-a randomised double-blinded placebo controlled trial. PloS ONE 2011;6:e17366.

292 Brenchley R, Spannagl M, Pfeifer $M$, et al. Analysis of the bread wheat genome using whole-genome shotgun sequencing. Nature 2012;491:705-10.

293 Gil-Humanes J, Piston F, Tollefsen S, et al. Effective shutdown in the expression of celiac disease-related wheat gliadin T-cell epitopes by RNA interference. Proc Natl Acad Sci U S A 2010;107:17023-8.

294 Matysiak-Budnik T, Candalh C, Cellier C, et al. Limited efficiency of prolyl-endopeptidase in the detoxification of gliadin peptides in celiac disease. Gastroenterology 2005;129:786-96.

295 Mitea C, Havenaar R, Drijfhout JW, et al. Efficient degradation of gluten by a prolyl endoprotease in a gastrointestinal model: implications for coeliac disease. Gut 2008:57:25-32.

296 Pyle GG, Paaso B, Anderson BE, et al. Effect of pretreatment of food gluten with prolyl endopeptidase on gluten-induced malabsorption in celiac sprue. Clin Gastroenterol Hepatol 2005;3:687-94.

297 Gass J, Bethune MT, Siegel M, et al. Combination enzyme therapy for gastric digestion of dietary gluten in patients with celiac sprue. Gastroenterology 2007:133:472-80.

298 Tye-Din JA, Stewart JA, Dromey JA, et al. Comprehensive, quantitative mapping of T cell epitopes in gluten in celiac disease. Sci Transl Med 2010;2:41ra51.

299 Gopalakrishnan S, Durai M, Kitchens K, et al. Larazotide acetate regulates epithelial tight junctions in vitro and in vivo. Peptides 2012;35:86-94.

300 Paterson BM, Lammers KM, Arrieta MC, et al. The safety, tolerance, pharmacokinetic and pharmacodynamic effects of single doses of AT-1001 in coeliac disease subjects: a proof of concept study. Aliment Pharmacol Ther 2007; $26: 757-66$

301 Leffler DA, Kelly CP, Abdallah HZ, et al. A randomized, double-blind study of larazotide acetate to prevent the activation of celiac disease during gluten challenge. Am J Gastroenterol 2012;107:1554-62.

302 Hoffmann K, Alminger M, Andlid T, et al. Blocking peptides decrease tissue transglutaminase processing of gliadin in vitro. J Agric Food Chem 2009:57:10150-5.

303 Stoven S, Murray JA, Marietta E. Celiac disease: advances in treatment via gluten modification. Clin Gastroenterol Hepatol 2012;10:859-62.

304 van der Windt DA, Jellema P, Mulder CJ, et al. Diagnostic testing for celiac disease among patients with abdominal symptoms: a systematic review. JAMA 2010;303:1738-46.

305 Mooney PD, Evans KE, Singh S, et al. Treatment failure in coeliac disease: a practical guide to investigation and treatment of non-responsive and refractory coeliac disease. J Gastrointestin Liver Dis 2012:21:197-203. 